\title{
Sephardic Hebrew Bibles of the Kennicott Collection ${ }^{1}$
}

By

\section{$\mathrm{M}^{\mathrm{a}}$ Teresa Ortega-Monasterio}

CSIC, Madrid (Spain)

$\mathrm{T}$

The Bodleian Library holds one of the best collections of Hebrew manuscripts in the world. Some of the most representative Hebrew bibles copied in the Iberian Peninsula are in this library, such as all included in the Kennicott collection, made up of nine bibles. Kenn 1 is the famous Kennicott Bible, which has been already studied, which I am not going to include in my work ${ }^{2}$. The Kennicott manuscripts transferred from the Radcliffe Library, where Benjamin Kennicott (1718-1783) had been librarian, to the Bodleian in 1879.

\footnotetext{
${ }^{1}$ This work has been carried out working directly with the manuscripts at the Bodleian Library, during my stay as visiting scholar at the Oxford Center for Hebrew and Jewish Studies in Oxford, Hilary Term, 2014 and within the framework of the research project Legado de Sefarad. La producción material e intelectual del judaísmo sefardí bajomedieval (Ref. FFI2012-38451) and Patrimonio Cultural Escrito de los Judíos en la Península Ibérica (Ref. FFI2012-33809).

${ }^{2}$ The Kennicott Bible. Facsimile editions, London, 1985; B. NARKISS and A. CoHEN-Mushlin, The Kennicott Bible, London, 1985.
} 
We have no specific information about how Kennicott gathered those manuscripts. But we know that one of his main projects was the study of the text of the Bible. In order to achieve this work, he collated a large amount of manuscripts during all his life and published a dissertation comparing different texts ${ }^{3}$. The Bodleian Library kept among its documents a large number of bundles keeping all collations, written by Kennicott himself or by his collaborators. The volumes are distributed by libraries and manuscripts, and represent a vivid testimony of his work, as a complement to his publications on this matter. ${ }^{4}$ The collations were prepared during the tour which he made to many European libraries between 1770 and 1773. It includes manuscripts from Paris, Louvain, Köln, Turin, Milan, Rome, Florence, Bologna Venice, Vienna, Dresden, Berlin, Hamburg, Kassel and Leyden. They bear the following shelfmarks from the Bodleian Library: Ms. Kennicott a.1, b.1-3, c.1-26, d.1-26, e.34-43 (Neubauer 2432) and Kenn 9 (N 2341), which under the title Liber Discrepantiarum or ספר השינויים, includes different readings in the Targum, in Latin and Hebrew (see pl. I) . The manuscript contains a document (fols. 3r-4r) signed by Joannes Antonius Constantius ${ }^{5}$ in Rome in 1761, where the collations of some manuscripts in the Vatican Library are mentioned.

Until now, good descriptions of Kenn 1 and 2 have been published, very detailed, but not of the other codices. The only catalogue is that of Neubauer's, from $1886^{6}$, and obviously lacks of important details about the texts. Moreover, Neubauer affirms in his catalogue: «nobody expects to have minute details about the Masorah " (Preface, p. 7). An additional volume has been published by M. Beit Arié in 1994 but only refers to some of the manuscripts. ${ }^{7}$ The manuscripts are also included in

\footnotetext{
${ }^{3}$ B. KennicotT, A Dissertation in Two Parts: Part the First compares I Chron. XI with 2 Sam. V and XXIII; and Part the Second contains Observations on Seventy Hebrew mss, with an Extract of Mistakes and Various Readings, 2 vols, Oxford, 1753.

${ }^{4}$ B. KenNiCOTt, The Ten Annual Accounts of the Collation of Hebrew Manuscripts of the Old Testament: Begun in 1760 and Compleated in 1769, Oxford - Cambridge - London, 1770 ; ID., The State of the Collation of the Hebrew Manuscripts of the Old Testament : At the End of the Ninth Year,. Oxford - Cambridge - London, 1768.

${ }^{5}$ Professor of Hebrew language in the Vatican Library and in the Colegio Urbano de Propaganda Fide, at the service of Cardinal Zelada (17171801).

${ }^{6}$ A. Neubauer, Catalogue of the Hebrew Manuscripts in the Bodleian Library, London, 1896-1906.

${ }^{7}$ M. BeIT ARIÉ, Catalogue of the Hebrew Manuscripts in the Bodleian Library. Supplement of Addenda and Corrigenda to Vol. I (A. Neubauer's Catalogue), Oxford 1994.
} 
SfarData webpage ${ }^{8}$, but with limited information. The nine Kennicott bibles are all Sephardic, except Kenn 3 (Neubauer 2325) and Kenn 10 (Neubauer 2324) which are of Ashkenazi origin and Kennicott 8 (Neubauer 2332) which is Italian. Only Kenn 2 reproduces the whole bible and has received special attention. A description was given by Bezalel Narkiss in $1982^{9}$, and also some details were offered by Katrin Kogman-Appel in 2004. ${ }^{10}$ It is dated in 1306 in Soria (Castile), being the scribe and illuminator the same person, the famous Joshua ibn Abraham ibn Gaon, copyist of other important bibles now in the the $\mathrm{BnF}$ (Heb 20 and 21). First Ibn Gaon Bible (Heb 20) is signed in the decorative Masorah magna and is dated in Tudela (Navarre), 1300. In Heb 21, he signed in a micrography stating that he has executed the manuscript and the Masorah. Kenn 2 is signed in the colophon which appears after the plan of the Temple, before the text of the bible (fol. $2 \mathrm{v}$ ). ${ }^{11}$

All Ibn Gaon manuscripts mentioned have similar characteristics in their decorations: geometrical designs for the Masorah magna, grotesques, dragons, lions, or vegetal motifs. Sometimes appear a human head in penwork, as in the panel decorating the parašah signs in Second Kennicott Bible. This one includes very frequently designs of three tower castles, lions or fleur de lys, symbols of the kingdoms in the Peninsula (see pl. II). Even more, we can find a crescent, which is a clear influence of Islamic art. The formula 'blessed be God forever and ever, amen, amen' appears at the end of some long micrographic Masorahs, as in fol. 110r. This formula is very frequent in manuscripts copied by Ibn Gaon.

The rest of the manuscripts of Kennicott collection are incomplete, lacking of some books in each case. One of them, Kenn. 4, belong to the so called "liturgic Bibles", including Pentateuch and Megillot. But nevertheless, all of them are relevant codices which deserve a detailed description and which can help to identify special characteristics of Sephardic Bibles. Codex Kenn. 7, dated in Toledo in 1222, belong to the same copyist (Israel ibn Isaac ibn Israel) of ms. 44a of the Jew-

\footnotetext{
${ }^{8}$ http://sfardata.nli.org.il

${ }^{9}$ B. NARKISs, Hebrew Illuminated Manuscripts in the British Isles, 2 vols., Jerusalem - London, 1982, 1, p. 24-30.

${ }^{10}$ K. Kogman-ApPEL, Jewish Book Art between Islam and Christianity. The Decoration of Hebrew Bibles in Medieval Spain Leiden-Boston, 2004, p. 101-114 and 116-118.

${ }^{11}$ The manuscript Opp. Add. $4^{\circ} 75$ of the Bodleian Library is also a Bible of Ibn Gaon. It includes Former Prophets with Targum. Another Ibn Gaon Bible is kept in the Trinity College in Dublin. It is dated ca. 1300 again in Tudela, and has no colophon, but a note in micrography where Ibn Gaon responds for the copy.
} 
ish Theological Seminary in New York. This Pentateuch is dated in 1241, also in Toledo, and is considered an authentic copy of the model codex Hil $\cdot l e l i$, since its colophon affirms that «it has been carefully corrected according to the model codex Hil·leli». Nevertheless, in some works has been demonstrated that the agreement between this manuscript and the readings considered from the Hil $\cdot$ leli represents only about a $66 \%{ }^{12}$ Kenn 7 refers in its Masorah parva in twelve times to the codex $\mathrm{Hil} \cdot \mathrm{leli}$, comparing the reading offered by its text with the reading considered as model.

In the present work, I shall deal with the biblical manuscripts of the Kennicott collection written in the Iberian Peninsula, including two aspects: the first one corresponds to the description of the codex. In the second one, textual aspects will been revised, since the texts included in micrographies and masoretic lists are often shared by manuscripts produced in the same geographical areas or by same scribes. My purpose is to prove the textual uniformity of Spanish codices and its proximity to the Tiberian tradition. In addition, I shall give a physical description of each manuscript.

Only one manuscript is illuminated: Kenn 2. The rest of the codices present some penworks around parašah or seder signs, sometimes also when the scribe introduces indication of the middle of the book. Micrographic decorations are more frequent, being similar to other Sephardic manuscripts from $13^{\text {th }}$ $15^{\text {th }}$ Centuries.

\section{Kennicott $2^{13}$}

The codex reproduces the whole Hebrew Bible, and is constituted by one codicological unit, copied by Joshua ibn Gaón in Soria in $1306 .{ }^{14}$ It is an illuminated Bible with II+428 folios, being its measures 308x235 mm with a text block of 237 x 145 $\mathrm{mm}$ (including Masorah). It is written on a high-quality parchment, with some holes that do not affect readability. The manu-

${ }^{12}$ M. T. ORTEGA-MONASTERIO, «Los códices modelo y los manuscritos hebreos bíblicos españoles», Sefarad 65, (2005), p. 353-383.

${ }^{13}$ Former Signatures: Kenn 2, N. 2323. Previous catalogues: NEUBAUER 2323. Bibliography: NARKISS 1982, 1, p. 224-30; NEUBAUER, 2323; KoGMAN-APPEL 2004, p. 61-62; 100-114; 98-130. NORDSTRÖM 1971, p. 3974.

${ }^{14}$ After the correction made by Beit Arié in Catalogue of the Hebrew Manuscripts in the Bodleian Library. Supplement of Addenda and Corrigenda to Vol. I (A. Neubauer's Catalogue), Oxford 1994, p. 1, the manuscript should be copied in 1303/4. He affirms that the last line in the colophon also belongs to the scribe. 
script conforms to Gregory's Law ${ }^{15}$ and is distributed quite regularly in 39 quires of 12 folios each although there are some exceptions : $2+8+3+12^{8}+8+12^{6}+16+12+10+12^{10}+10+12^{2}+10+$ $12^{2}+9+4$. It has reinforcing strips on all quires. Quire catchwords appear usually in the lower left margin, in the scribe's hand. Others are added later in a second hand, as in fol. $61 \mathrm{v}$ (perhaps because the original catchword was cut off when the volume was bound). The modern pagination in pencil using Arabic numerals has been corrected. There is another pagination that begins at the end of the codex and is upside down. The book titles are added in Latin.

Ruling is very visible on the recto side of the folios, in plummet, with horizontal and vertical lines, following the outline of the text and Masorah, as occurs frequently in Iberian codices. ${ }^{16}$ The pricking is also visible in the outer margins of the pages, creating a uniform vertical line, although in places it is cut off due to binding. The text is written in two columns, generally of 34 lines. The Masorah parva occupies the intercolumnar space and the Masorah magna, two lines in the upper and three in the lower margins, often taking micrographic forms with illuminations.

The codex is written in Sephardic square script with Tiberian punctuation, in dark brown ink for the text and slightly lighter for the Masorahs, without any significant corrosion. Frequent micrographies appear throughout the manuscript, except in the books of the Ketuvim and thereafter.

The manuscript has a decorative program that has been studied in detail. ${ }^{17}$ First of all, there is a Temple drawingunrelated to the other decoration-on fols. $1 \mathrm{v}-2 \mathrm{r}$, which according to the colophon, was also executed by Ibn Gaón. This drawing and all the other illuminations in the manuscript are described in detail by Narkiss. The two folios showing the Temple drawing are bound incorrectly: fol. $2 \mathrm{r}$ has been rotated, so that the two halves of the drawing do not match up. Also, part of the design is missing, having been lost. The drawing includes the Temple's architectural features as well as many temple implements. Various colors of ink are used: black, red,

15 Rule used in codicology corresponding to the consistent medieval practice of collating parchment leaves so that grain side faced grain side and flesh side flesh side.

16 «In Spain and other Sephardic areas visual clarity of the ruling scaffoldings, which ensured aesthetic and uniform copying, was preferred over low cost.» M. BEIT-ARIÉ, Unveiled Faces of Medieval Hebrew Books, Jerusalem, 2003, p. 31.

17 NARKISS, Hebrew Illuminated Manuscripts, 1, p. 24-27. Given this excellent description of the manuscript's entire decorative program, I limit myself here to outlining the most important elements. 
blue, green, yellow and brown, as well as gold decorations. There are inscriptions with the names of some rooms, gates, and areas.

Another decorative element is the frames, which take up the entire space around the text, as can be seen on fol. 1r around the colophon. This one is an interlaced design done in the mudéjar style in red. Lists of precepts and masoretic lists are framed by red and green lines and, around that, by text in large, golden letters, as in fols. 204v-205r. The lists on fols. 3r-13r are also written in two columns framed by arches-horseshoe, pointed, multi-lobed, or simply rectangular-in red, green, or gold. They include drawings of animals (dragon, bird) or vegetation. Fol. 13v lacks decoration.

Carpet pages: In four cases, carpet pages take up the whole page (fols. $14 \mathrm{r}$ to $15 \mathrm{r}$ and $117 \mathrm{v}$ ), decorated with interlaced geometric motifs and including - as also happens in many other places throughout the manuscript - a castle, in allusion to the kingdom of Castile. In two other cases, these interlaced panels occupy only half the page (fols. 299r and 427r). In all cases, a wide variety of colors are used (red, blue, green, and gold).

Micrographic decoration: The Masorah magna very often takes the form of micrographies, with different additional motifs, generally in gold. Some examples are fols. 265v and 266r, where there is a downward-facing crescent; fols. 166r, 142r, and $298 \mathrm{v}$ have more drawings of a castle with three towers and several lions, symbols of the kingdom of Castile; dog heads can be seen on fol. $64 \mathrm{v}, 70 \mathrm{v}$, and $100 \mathrm{r}$; and in multiple places we find the fleur-de-lis, as on fol. $227 \mathrm{v}$, used as a royal symbol.

Decorative panels: Many of the parašah indications are decorated, usually in gold, with small panels in red and gold, as on fol. $4 \mathrm{v}$. Sometimes they do not have illuminations and they are marked only by the letters פרש, as on fol. 111v (Deut. 26:1). Larger-size letters are written in gold (fol. 67v), and the benedictions that can be found at the end of various Masorah magna notes are written in micrography with some golden ornamentation (fol. 98r) (see pl. III).

At the end of each biblical book, from the beginning of the manuscript up to and including the Minor Prophets, there is a decorative panel giving the verse count and indicating the middle of the book. At the end of the Pentateuch, the panel takes up the entire page, with the written text taking the form of a frame that encircles a drawing of interlaced geometric motifs in gold outlined in red. Below, a later annotation states: 'Vers in Pent.: 5830'. The beginning of each book has no special markings. This panel does not appear, at the end of each of the Minor Prophets, where there are simply four blank lines. The panel consists of a simple red box bordered by two golden lines, one inside the box, the other outside of it. Or the opposite: the box 
is gold and the lines, red. At the beginning of the Book of Song of Songs there is no panel with the count from the previous book, Ecclesiastes; but the first letter of the book, a šim, is of larger size and written in gold outlined with red. Beginning with the book of Ruth, decoration becomes less frequent and much simpler, as in fols. $311 \mathrm{v}-312 \mathrm{r}$, and is limited almost exclusively to the last page of a quire and the first of the next. In some cases, the decoration is even incomplete, as can be seen clearly on 323v-324r.

The colophon appears on fol. $2 \mathrm{v}$, written on lines that run the entire width of the page and surrounded by a frame of interlaced forms in mudéjar style, in red, green, and yellow, as a continuation of the text that occupies fol. $1 \mathrm{r}$, which is very damaged but has a similar interlace design. In the colophon, the scribe identifies himself as Joshua ibn Abraham ibn Gaón de Soria. It also mentions that the copy was completed in the month of Adar in the year 1306. This is on the last line, written in the same hand but with lighter ink, and some authors consider it to have been added later. ${ }^{18}$ The page (fol. 1r) begins with the text of Job 34:10 'So listen to me, you men of understanding':

בינ"ו נא אנשי לבב ראו גם ראו דעו והתבוננו איך הוכן בית אלהינו על מכונו

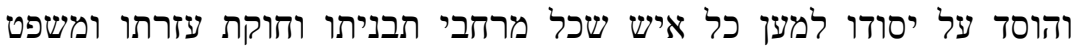

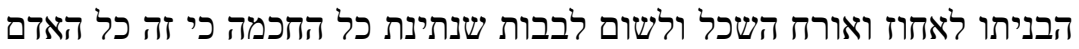

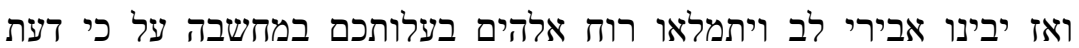

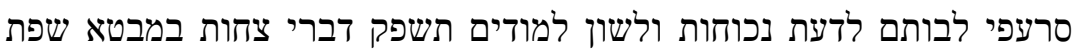

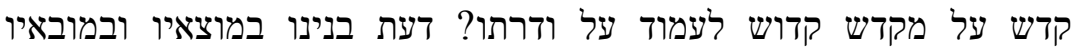

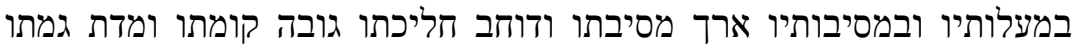

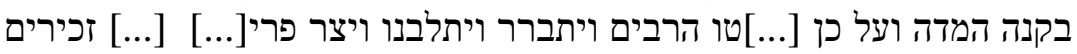
זהירו ויבינו וערו עם קדוש [..............

(8 lines are missing due to parchment damage caused by moisture)

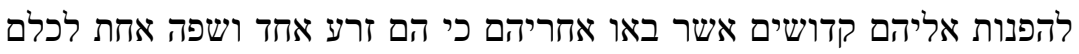

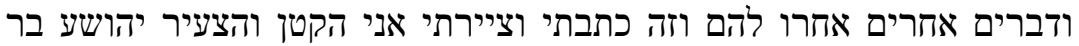

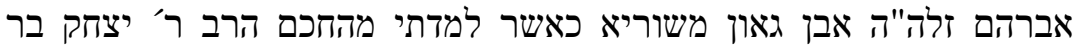

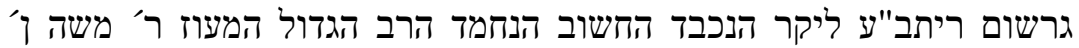

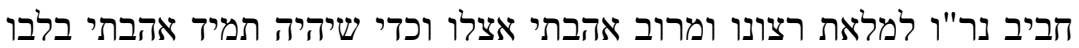

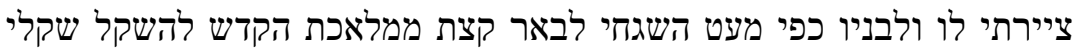

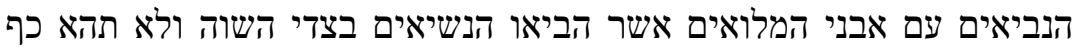

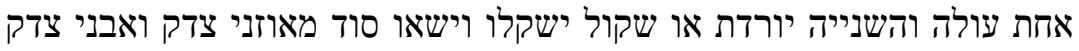

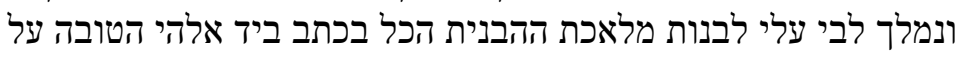

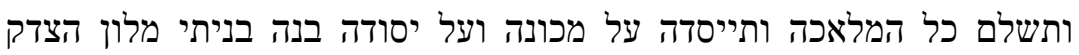

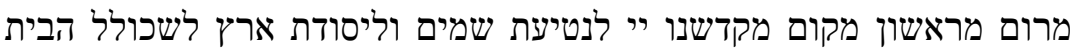

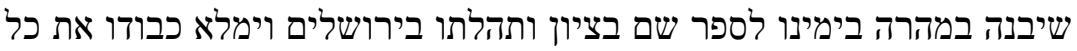
הארץ אמן ואמן ונגמר בחודש אדר שנת תתרס"ו לספר ליצירה בשורים ויאיא

\footnotetext{
${ }^{18}$ NARKISS, Hebrew Illuminated Manuscripts, 1, p. 24.
} 
The contents of the manuscripts is as follows: Exhortations addressed to the reader (fol. 1r), Temple plan (fols. $1 \mathrm{v}-2 \mathrm{r}$ ), continuation of the text from fol. $1 \mathrm{r}$ and colophon (fol. $2 \mathrm{v}$ ), Laws given by God to Moses (fols. 3r-13v), Gen (fols. 15v-40v), Exod (fols. 40v-62v), Lev (fols. 62v-77r), Num (fols. 77r-98r ), Deut (fols. 98r-117v), Josh (fols. 118r-131r ), Judg (fols. 131r-143v), 1 Sam (fols. 143v-160v), 2 Sam (fols. 160v174r), 1 Kings (fols. 174r-189v), 2 Kings (fols. 189v-204r), list of sedarim from Isaiah, Jeremiah, Ezekiel and Minor Prophets (fols. 204v-205v), Isa (fols. 206r-227v), Jer (fols. 227v-255r), Ezek (fols. 255v-280r), Minor Prophets (fols. 280r-299r), Ruth (fols. 300r-301r), Ps (fols. 301v-337v), Job (fols. 337v-352r ), Prov (fols. 352v-365r ), Eccl (fols. 365r368v), Song (fols. 368v-370v), Lam (fols. 370v-372r), Dan (fols. 372r-379v), Esth (fols.379v-383v), Ezra (fols. 383v388v ), Neh (fols. 388v-395v), and Chr (fols. 396r-427r).

The order of the Ketuvim and the Megil·lot coincides with that of the Talmud and with that of the M1 manuscript. ${ }^{19}$ Parašiyyot are indicated with the letters פרש פ or. From Josh. 1:1 to Judg. 14:1 and from Isa. 1:1 to the end of the Minor Prophets the sedarim are marked in a later, coarser hand, numbering them in Hebrew in a correlative way (e.g., Josh 4:24, fol. $119 v)$. The Psalms are numbered in Hebrew in the margin by the principal scribe. The chapters are numbered in pencil by a much later, Christian hand.

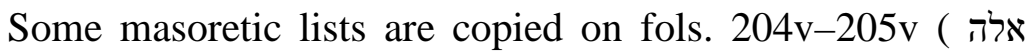
הסדרים של ארבעת ספרים האחרנים בכל ספר וספר ישעיהו: Lists of sedarim from Isaiah, Jeremiah, Ezekiel, and Minor Prophets) and fols. 3r-13v ( אלה המצות אשר צוה ה' את משה אל בני ישראל בהר סיני : Lists commandments given by God to Moses on Mount Sinai).

Ibn Gaón often uses a formula praising God that he writes at the end of the Masorahs in the form of micrography, as we can see on fols. 189 v, 98r, 43v, 44r and on 110r: ברוך יי לעולם אמן אמן, sometimes with minor variations.

The manuscripts copies some notes of purchase which can help us to reconstruct part of its history. For example, on fol. $427 \mathrm{v}$ it reads:

בפנינו עדים חתומי מטה הודה החכם הישיש המעולה כה"ר שמואל פארזנט

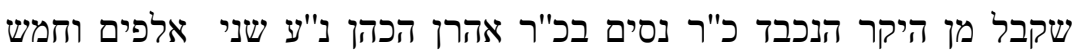

\footnotetext{
19 Manuscript M1 (118-Z-42) at the library of the Universidad Complutense in Madrid. See description in F. J. DEL BARCO DEL BARCO, Catálogo de Manuscritos Hebreos de la Comunidad de Madrid, Madrid, 2003, I, p. 109-112. The order of these books also coincides with that of Harl 1528, Add 1525, Or 2212, 2375 and 4227 manuscripts, all of which are held in the British Library. On the order of the books, see C. D. GINSBURG, Introduction to the Massoretico-Critical Edition of the Hebrew Bible, with a Prolegomenon by H. M. ORLINSKY, New York, 1966, p. 7, col. 1.
} 


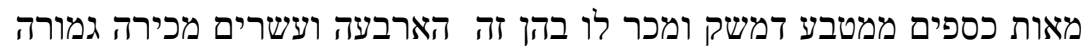

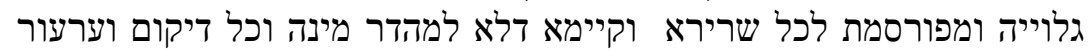

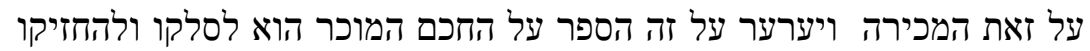

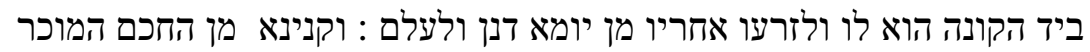

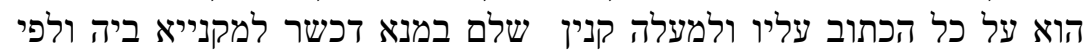

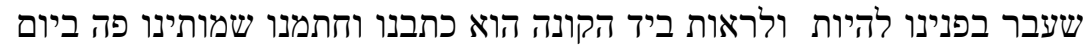

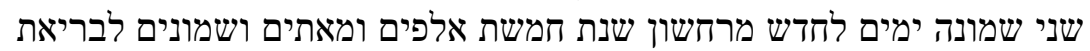

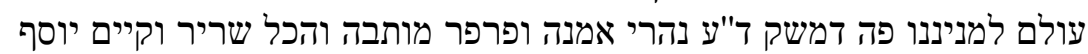
פלכון... סופר.... יצחק....

This text is written in a Sephardic cursive script and states that Samuel Parzant bought the manuscript from R. Nissim ibn Aaron ha-Cohen on October 2, 1519, for 2500 Damascus coins. The names Amana and Parper belong to two rivers that flow through Damascus, mentioned in 2 Kings 5:12.

The codex is bounded in tobacco-colored leather with embossing on the center piece, frame, and interior corners with floral designs in deep-red, probably from the seventeenth century. The interior (covering and turn-in) consists in a floral paper with a dark red background and drawings in gold of vegetal design.

\section{Textual Characteristics}

The text is meticulously written in an excellent Sephardic square script of medium size. In many places there are corrections made by the scribe himself, or secondary hands can be perceived over erased text, for example, in 1 Sam 22:16. The fragment of Num 7:18-83 is incompletely vocalized, though not in the same way as in other manuscripts. Whereas usually none of the verses in this section are vocalized, this manuscript vocalizes a verse here and there, leaving the rest of them with accents only (fols. $81 \mathrm{v}-82 \mathrm{v}$ ).

To complete lines, the manuscript generally uses the technique of enlarging some letters, although in places the first two consonants of the first word of the following line are written unvocalized or the letter yod is written. Often the last word on the line is compressed; in cases where there is a sof pasuq at the end of the line, a blank space is left between the last word and the sof pasuq. On fol. 198r the second column of text is wider than the first, and the text is more compressed than usual. The scribe wrote in this column a longer text than what had been planned. Also in Job 12:17-18 some text is added in the margin (fol. 341v).

The manuscript includes the two verses Josh. 21:36-37, noting in the MP: אלו השני הפסו אין כתובי לא בבבלי ולא בהללי, citing the Codex Hil-leli and the Codex Babli as a reference. Neh 7:68 is also included, without a note. 
is written without a dageš in the nun (Josh 1:1, Num 13:8), בית־ as two words (Gen 31:13 [fol. 29v] and Gen 35:3 [fol. 31v]), and כדרלאמר as only one word, as in the passages Gen $14: 1,4,5,9$, and 17 , with a note written in a second hand in the MP to Gen 14:1 stating that in the most-precise texts it is written this way, although some Masorahs say that it should be two words. Also, יששכר is punctuated with a dageš in the sim, according to the reading of Ben Asher, as in Exod 1:3 (fol. 40v) and Num 1:28 (fol. 77v). Extraordinary points are written in the customary way. ${ }^{20}$

When the word יהוה is to be suppressed, it is encircled in a continuous black line and is not crossed out or erased, as can be seen on fol. 180v, 1 Kings 9:6, where the word יהוה is written by mistake after מאחרי. The same thing happens twice on fol. 198 r.

The manuscript rarely uses the meteg, even before a hatef šewá, as can be seen in the following cases:

\begin{tabular}{|c|c|c|}
\hline Dan 10:1 & וֶאֶֶֶ & Dan 10:15 \\
\hline Dan 11:7 & וְהָחֶֶׁיק & Dan 8:27 \\
\hline Dan 9:7 & 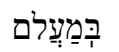 & Dan 9:11 \\
\hline
\end{tabular}

And normally the dageš is not put in a consonant that follows a guttural with a šewá, as in

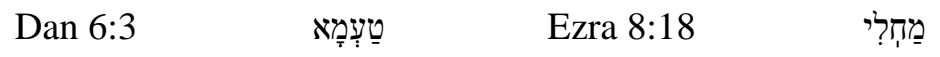

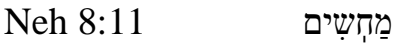

Nor in the first letter of a word preceded by the same letter:

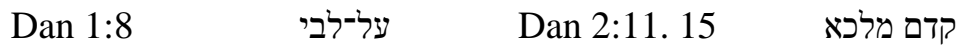

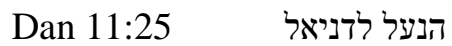

When a consonant with a simple šewá is followed by the same consonant, the šewá is not replaced by a hatef pataḥ:

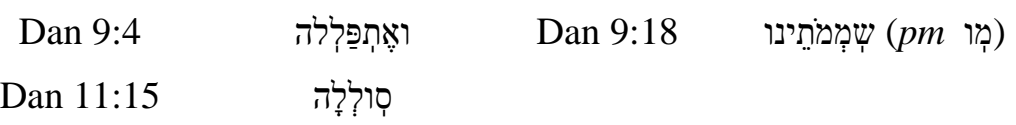

The Masorah is written meticulously in very small but extremely clear lettering. A second hand appears very frequently

\footnotetext{
${ }^{20}$ On extraordinary points, see GINSBURG, Introduction, 318-334 and M. J. DE AZCÁRRAGA, «The Ortographic Irregularities in the Manuscript M1 of the Library of the Universidad Complutense de Madrid», Sefarad 59 (1999), p. 239-250.
} 
in the Masorah, using a lighter ink and slightly less uniform handwriting. This hand adds notes or text fragments that were omitted when the biblical text was copied or makes reference to the model codices, as we will see below. On a few occasions, the entire Masorah on the page is written by this second hand, as on fols. 262r and v. In this case, neither the page nor the bifolio are added, which leads me to believe that this second hand is contemporaneous with the copyist. We have numerous examples of additions and corrections made by this second masorete. For example, on fol. 157r, 1 Sam 25:3, a text is added in the margin that had been omitted due to homoioteleuton. On fol. 123r (Josh 10:23), we see the same thing.

Frequently in the Pentateuch though rarely in the rest of the Bible, the MP uses the expression וחלוף to indicate a reading contrary to what is given in the masoretic information or in the text. In Deut 20:19, concerning the word תצור the MP says: ל וחלוף נפש יקרה תצוד referring to the fact that the case of Deut is written with reš and that of Prov 6:26 with dalet. Also in 1 Kings 8:7, concerning the word ויסכו the MP says: ל וחלוף וישכו. Frequently, the notes in the MP indicate the textual variants in the manuscript compared to the textus receptus, generally offering a different spelling.

The Masorah often mentions in an indeterminate way "some exact texts" to indicate correct readings. For example, in Gen 14:18 (fol. 20v), concerning the word ומלקי צדק the MP, written by a second hand, says: בנוסחי דיקין חד מלה כת ובמסורה תרין הילדך יעביד תרין מלין וחד שנוא, explaining the difference between the opinion given in the Masorah and other correct texts. In other places, the masorete expresses the opinion of commentators such as Abraham ibn Ezra. Concerning the word מקרה in Deut

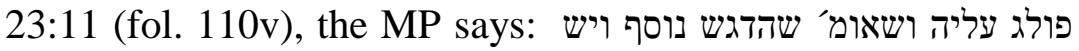
:אומ' שהמם הוא משרתת והוא לאבדהם ן' עזרא ז"ל על כן אין הדגש נוסף 'there is a discrepancy about this word; there are those who say that the dages has been added and there are those who say that the mem is servile. But R. Abraham ibn Ezra says about this that the dageš has not been added.'

This second hand that appears in the Masorah is the one that indicates many cases of qeré that were not included by the first hand, as happens in the book of Daniel, on fols. 378r - v and several other places. This hand has also written a series of annotations about punctuation that differ on the customary information in the Masoretic notes, as in Ezek 18:6 (fol. 262v), concerning the vocalization of לא אכל, where the annotation explains that the patah in אכל is an open patah ומאן דלו אכל קמץ. 


\section{Model codices}

Three model codices are mentioned in the Masorah parva of the manuscript: the Codex Hil-leli, the Codex Babli and the Codex Muggah. These are reference codices, considered to be very exact with respect to the most correct tradition of the biblical text. ${ }^{21}$ The most frequently cited of the three, by far, is the Codex Hil·leli. The masoretic notes referring to these codices are always in a second hand, in a less regular script that is bigger than that used by the first hand of the Masorah and in lighter ink. In several places, the text in the manuscript differs from others that are mentioned and concurs with the text of the Codex Hil-leli. But in the majority of cases, the text of Kenn 2 is different from the model codex, and in some places the reading of the manuscript even differs from that of the masoretic text according to the Leningrad Manuscript. There are also cases in which the text is clearly corrected in order to make it agree with the reading of the model codex. The passages where model codices are quoted are the following:

\section{Codex Hil·leli}

Lev 4:5

MP

L

Josh 5:1

MP

L

Josh 8:22

MP

$\mathrm{L}$

2 Sam 10:3

MP

$\mathrm{L}$
והבְיא אתֶו אל־אֶהל

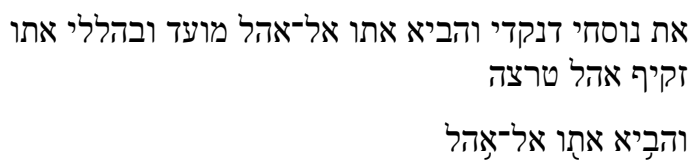

כשמעע (over erasure, pm כ)

כן בהללי היה רפי וצור

כשמע

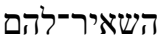

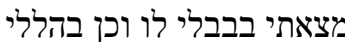

לו

ולרגלה

בהללי ולרגלה רפי

ולרגלה

${ }^{21}$ For more information on these codices, see GINSBURG, Introduction, p. 429-437; M. T. ORTEGA-MonASTERIO, «El texto de los Códices Modelo según el 'Or Torah de Menahem de Lonzano», in N. FERNÁNDEZ MarCos, J. Trebolle Barrera y J. Fernández Vallina (eds.), Simposio Bíblico Español , Madrid, 1984, p. 193-212. 
1 Kings 3:15

MP

$\mathrm{L}^{22}$

1 Kings 12:2

MP

L

2 Kings 5:6

MP

$\mathrm{L}^{23}$

Isa 30:12

MP

L

Isa $38: 16$

MP

L

Jer 13:17

MP

$\mathrm{L}^{24}$

Jer 51:34

MP

L

Ezek11:19

MP

L

${ }^{22}$ BHS refers to this variant as common to many other manuscripts.

${ }^{23}$ See G. WEIL, Massorah Gedolah. Manuscrit B19a de Léningrad, Rome, 1971, I, p. 77, list 639.

${ }^{24}$ Ibid., p. 282, list 2501.
אדני

ובהללי יהוה - - - - - - - - n

יהוה

(המלך שלמה over erasure, pm) שלמה המלך

כן בהללי ובבבלי המלך שלמה

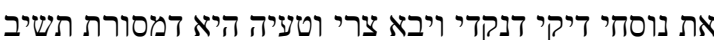

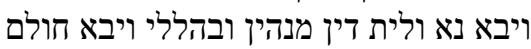

ובהללי בַעשק כת

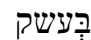

יהוה

בבבלי אדני כן בהללי

אדני

בהללי עינַי

עיני

מלא

כן בהללי בצרי מלא

מלא

בקרבם

בהללי בקרבכם

בקרבכם
המלך שלמה 
Ezek 41:24 (2 $\left.{ }^{\text {nd }}\right)$

שתים

MP

בהללי שִתים

L

שֶתים

\section{Codex Muggah}

Isa $17: 11$

נַחלה

MP

כך במוגה נְחלה - כלוחה

L

נַחלה

Ezek 16:63

לכל אשר עשית

MP

במוגה לכל-אשר עשית

L

לכל-אשר עשית

Codex Babli

Josh 8:22

השאיר-להם

MP

מצאתי בבבלי לו וכן בהללי

L

לו

Josh 8:24

אשר רדפום שם

MP

בבבלי בו

L

בו

1Kings 12:2

(המלך שלמה over erasure, pm שלמה המלך

MP

כן בהללי ובבבלי המלך שלמה שלה קות

L

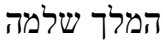

Isa 38:16

יהוה

MP

בבבלי אדני כן בהללי

$\mathrm{L}$

אדני

As can be seen, in fourteen cases the Masorah cites the Codex Hil.leli; in four of them the text of Kenn 2 coincides with the text of the Codex Hil·leli, but in the rest it is different, including from the reading of the Leningrad Manuscript. The Codex Muggah is cited in only two cases, in one of which Kenn 2 coincides and the other it does not. And in none of the four 
cases where the Codex Babli is cited in the text of Kenn 2 does the manuscript coincide with the model codex. It is likely that the masorete who penned these Masorahs wanted to point out the nonconformity of the text he was annotating with important sources in cases that he considered to be especially relevant.

\section{Kennicott $4^{25}$}

The manuscript is a Hebrew Pentateuch with haftarot and Megil.lot, one of the so called liturgical bibles. It constitutes one codicological unit, copied in Castile (Toledo?) in 1318. It has I+366 folios, being its measures $315 \times 255 \mathrm{~mm}$, (the text block is $240 \times 185 \mathrm{~mm}$ including the Masorah). It is written in a high quality parchment, conforming to Gregory's Law, although it does not present much difference between both sides of the parchment. One folio with its text lacks after fol. 357: it has been cut, remaining the stub. The last folio is cut in half lengthwise, in an irregular form. The parchment presents some stains due to humidity, mainly at the beginning of the codex, whit does not prevent the correct reading of the text. It has also some holes due to imperfections in the parchment, as in fol. 86r, which do not affect readability.

The codex is very regularly distributed in 47 quires of 8 folios in most of the cases: $8^{14}+6+8^{30}+6^{-1}$ (one folio has been cut, the stub remaining)+2. It has no quires or pages catchwords. It is paginated using Arabic numerals in pencil and a second and erroneous pagination appear in the upper right angle of each folio, crossed out in many cases. The name of each biblical book is added with pencil in the upper margin in English, but only in the first page of each book. The same hand marks in the margins the biblical passages in the haftarot. The text is written in two columns, generally of 19 lines, being the ruling or pricking hardly visible.

The Masorah parva occupies the intercolumnar space and the Masorah magna, two lines in the upper and up to six in the lower margins, with some occasional micrographies. There is no Masorah magna in the Megil·lot, being rare the Masorah parva. At the end of each biblical book, appears count of chapters and verses.

The Hebrew text is written in a beautiful Sephardic square script, much larger for the text and smaller for the Masorah with Tiberian punctuation in dark brown ink for the text and slightly lighter for the Masorahs and punctuation, without any significant corrosion (see pl. IV).

The manuscript has no illuminations or special decorations, with exception of some micrographic decorations in geometric

\footnotetext{
${ }^{25}$ Former Signatures: Kenn 4; N.2326. Previous catalogues: NEUBAUER 2326.
} 
forms, very simple. Some of them are similar to manuscript Heb 24 of the BnF, fol. 86r or 143r, 222v (3 circles in vertical bound by straight lines). In some occasions, the sign of seder appears surrounded by a simple penwork, as in fol. $11 \mathrm{v}$. No decoration appears in the haftarot.

At the end of the Pentateuch, in fol. 269r and written by a different hand appears the colophon: נשלם זה הספר שליש ראשון השישי (=ע"ח)לח' סיון שנת גאל יגאל לאלף, specifying the date: month of siván, year 1318.

The contents of the manuscripts is as follows: Gen (fols. 1v69v), Exod (fols. 69v-127v), Lev (fols. 127v-166r), Num (fols. 166r-221r), Deut (fols. 221r-269r) and Haftarot (fols. 269v339r), Ruth (fols. 339v-342v), Song (fols. 343r-346v), Eccl (fols. 346v-354r), Lam (fols. 354r-357v), Esth (fols. 357v$365 \mathrm{v}$ ). The order of the Megil.lot agrees with those of many Sephardic manuscripts ${ }^{26}$. Parašiyyot are indicated with the letters פ פרש or and sedarim marked with $0 .{ }^{27}$ At the end of each parašah, mnemotechnique words indicate the number of verses of parašah, as frequently occurs in Sephardic codices. ${ }^{28}$ Numbers of all chapters and verses from five to five have been added in the margins.

The manuscripts copies some notes of purchase. On fol. $5 r$ there is a note in oriental semicursive script: מקנת כספי יצחק; in fol. 121r, in a very blurred Sephardic semicursive script Yi haq Qaldilon (Calderon?), as owner, is quoted in Spanish language: ... אשטי ליב[י[לו איש די יצחק קאלדילון; in fol. 351r in very small semicursive script reads «probationes calami»; and finally, in fol. 366r copies a text of Tractate Hul-lin 13,1 with some variants:

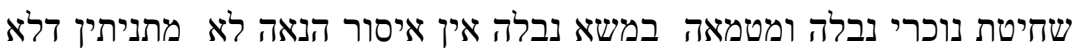

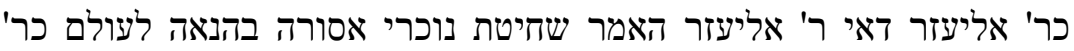

אליעזר

The manuscript is bounded in dark brown leather with dark stains, probably from eighteenth Century. Flyleaves and covering come from a Hebrew book, containing fragments of the Maimonides Misneh Torah (Hilkot sejitá, hilkot terefá), laws of

${ }^{26}$ GINSBURG, Introduction, 4, list 3.

${ }^{27}$ G. Sed Rajna connects the signs of seder with manuscripts produced in Toledo, G. SED-RAJNA, «Toledo or Burgos», Journal of Jewish Art, 2 (1978), p. 6-21. She also affirms that in Toledo the use of sexternions was frequent. This manuscript has 8 folios quires like other manuscripts from Toledo (Parma 2025).

${ }^{28}$ GINSBURG, Introduction, 67 and 71 and fols. In most cases it consists in a proper name with a numerical value identical to the number of verses. Depending of each scribe or school, variations can be found. Ben Hayyim edition of the Bible sometimes writes them. They appear in manuscripts BL Or 4445, M1, Or 2201, and Or 2626-28. 
Judaism concerning ritual purity and cleanliness, slaughtering, etc.

\section{Textual Characteristics}

The text is written in excellent Sephardic square script, with dark brown ink. The Masorah presents occasional annotations, sometimes in its same hand (as in fol. 111v) but also with different hands. A second semicursive script, in black ink and larger size corrects occasionally the Masorah, as in fols. $48 \mathrm{v}$, $40 \mathrm{v}, 39 \mathrm{v}$, or $25 \mathrm{r}$. Another oriental semicursive script, smaller and thoroughly done, adds some annotations to the Masorah, as in fol. $109 \mathrm{v}$, where even the circellus is added, as the referred ward אהרן had no Masorah.

To complete lines, the manuscript generally uses the technique of enlarging some letters or introducing a separation between words. In other occasions, the last word or words of the line are compressed. Corrections to the text are scarce, with few erasures, except some of them more visible, as in the first line of fol. 197v in Num 20:6. The manuscript does not vocalizes the passage of Num 7:18-83, writing only the accents, as it happens in Leningrad codex. Nevertheless, the unvocalized passage starts in 7:26. The extraordinary points are written in the customary way, giving sometimes a larger information in MP, as in Num 3:39 (fol. 170v). The MP about the word ואהרון says:

ינקודי בתו ודי נקוד כלו ולמה נקוד לפי שלא היה במני אלא מפני כבדו זכרו

אתו יקור

The manuscript writes בית־אל in two words, as in Gen 31:13 (fol. 40v), or Gen 35:3 (fol. 46r), even dividing the expression in two lines, as in Gen 12:8 (fol. 14v). It writes also כדרלאמר as a single word, as in the passages of Gen 14:1, 4, 5, 9, 17 and vocalizes יששכר with dageš in the sim, according to BA reading. In Gen 6:3, the word בשגֵ vocalizes with patah, not with qame as it is said to be the Hil-leli reading. In Gen 29:25

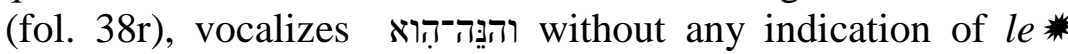
case. It writes בן־נון without dageš in the nun, after BA tradition, as in Num 11:28; $13: 8$ or 14,6 .

The rafeh is used very frequently. The manuscript rarely uses the meteg, even before a hatef sewá, as occurs in the most exact codices, as can be seen in the following cases:

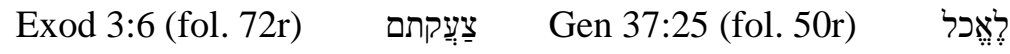

Gen 18:29 (fol. 21r) אֶֶָׁה 
Normally the dageš is not put in a consonant that follows a guttural with šewá, as in:

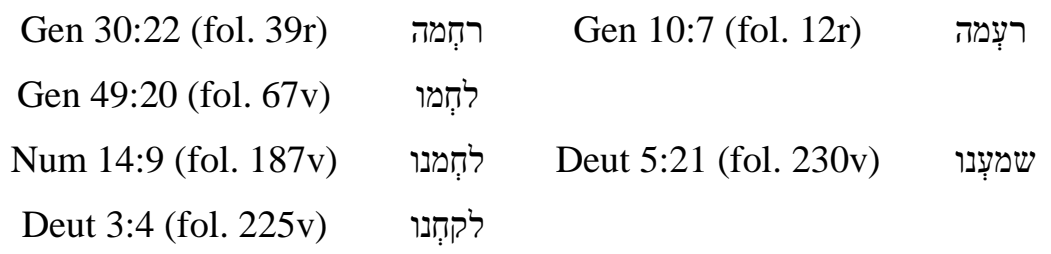

Nor in the first letter of a Word preceded by the same letter:

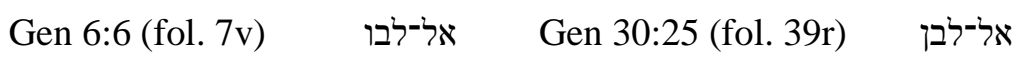

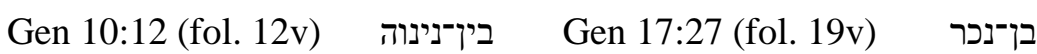

But dageš is present, as usually, in begadkefat letters:

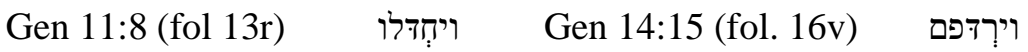

The manuscript does not change a šewá in hatef patah when a consonant with simple šewá is followed by the same consonant:

\begin{tabular}{|c|c|c|}
\hline Num 31:8 (fol. 212v) & חללליהם & Deut 32:6 (fol. 265r) \\
\hline Deut 32:10 (fol. 265v) & י יסבְבנהו & Lev 22:9 (fol. 156v) \\
\hline
\end{tabular}

The Masorah is written in smaller characters and with lighter ink, as usual, very clear and carefully done. When the MP is longer than usual it is written as a column, writing each word in each line, occupying the entire vertical margin. Occasionally, the note of MP seems to be properly a MM note, due to its extension, as occurs in fol. 95r, referring the word השלישי (2 $2^{\text {nd }}$.) in Exod 19:11, where the MP is developed, quoting the simanim of all cases ${ }^{29}$ or in fol. 70v referring the word הלכת where the MP is also developed, offering information about the rooth, which does not appear in other manuscripts. The same occurs in fol. 66v, with the word הבכור of Gen 48:11. Sometimes, the $\mathrm{MM}$ is written in the right margin in cross wise sense, when the space in both upper and lower margins was not as much as necessary (fol. $72 \mathrm{v}$ ). The Masorah includes frequently lists of unique cases, as it happens often in oriental manuscripts (Or 4445), even writing them in similar layout (fol. 63r, in lower $\mathrm{MM}$, fol.87v). Occasionally, to fill the lines a sign made up of little circles joined by a horizontal line is used, which is also very frequent in oriental manuscripts, as in fols. $17 \mathrm{v}, 18 \mathrm{r}, 14 \mathrm{r}$ o 63r.These features, similar to scribal devices of oriental manuscripts, can be due to its early dating, when still less contamina-

\footnotetext{
${ }^{29}$ See WEIL, Massorah Gedolah, I, p. 62, list 506.
} 
tion with other textual traditions or specifically Sephardic characteristics are present. The MP notes on occasions the differences between BA and BN, as in Gen 41:50 (fol. 56r), referring the word ילד. Its MP writes:

בן אשר פת בן נפאלי קמ וממסיר ב קמצי כי אדם

The MP uses frequently the expression וחלוף to indicate a contrary reading to the passage referred as in Gen 30:16 (fol. 39r), about the word שכר. Its MP says that, being a unique case, another with different accentuation can be found, with pašța in the kaf: ל וחלוף למען שכר הוא (Neh 6:13). In fact, the reading in the passage of Nehemiah is plene (שכוּר). The manuscript also uses the word פלוגתה for the same purpose, as in Gen 11,12 (fol. 13). The word וַימצאו writes in its MP: ל פלוג וַימצאו

At the end of each biblical book, in a very simple form, appear the total number of chapters, verses, words, etc.

\section{Kennicott $5^{30}$}

The manuscript copies the Former Prophets with Targum and commentary by Rashi, David Kimhi, and Levi ibn Gershon. It constitutes a single codicological unit, the work of a single copyist, Abraham Alabit: אברהם אלאביט and is dated in Segovia in 1487 (according to the colophon). ${ }^{31}$

The codex has III+262+III fols.; its measures are 345x275 $\mathrm{mm}$, being the text block 200x265 mm (including the Masorah parva and the commentaries). It corresponds to a large-format Bible and has no blank pages. It is written on parchment of good quality and medium thickness, conforming to Gregory's Law with some corrosion due to moisture, but in general does not hinder legibility. The first two folios are restored on paper, but this does not affect the text. It is distributed in 33 quires of 8 folios each, except the first and the last, in a very regular composition: $7+8^{31}+7$.

Quire catchwords appear on the lower left-hand corner in the same hand as the scribe's, although some are absent due to having been cut off during binding. An occasional catchword has been added in a later Sephardic semi-cursive script. There is another numbering system, which is much later and does not coincide with the quires, in the middle of the lower margin of each recto, using the Hebrew alphabet and including the final form of the letters, ending on fol. 86r. Modern pagination has been added in Arabic numerals in pencil and with corrections. At the top of each page, the biblical book and chapter are giv-

\footnotetext{
${ }^{30}$ Former signatures: none. Catalogues: NEUBAUER 2329. Bibliography: E. VAN STAALDUINE-SULMAN, 2009.

${ }^{31}$ Kasher dates the manuscript in 1594. See R. KASHER, תוספות תרגום לנבאים (Targumic Toseftot to the Prophets), Jerusalem, 1996.
} 
en; and in the margins, the verse numbers are written. The titles of books are added at the top in English. Drypoint ruling is visible on the recto side of the folios, with horizontal and vertical lines, marking the writing grid for the text and commentaries but pricking is not visible. The text is written in two columns, generally of 20 lines.

The manuscript has no Masorahs; the only indications in the MP are some qeré readings, in a darker ink and a different hand from the rest of the text.

The Hebrew Bible text and Targum in written in Sephardic square script with Tiberian pointing and the commentaries in Sephardic semi-cursive script. Written in the inner and outer margins is the text of the Targum, and in the upper and lower margins, the biblical commentaries of Rashi, D. Kimhi, and Ibn Gershon. The copyist uses brown ink for the biblical text. But the text of the Targum, some of the commentaries, as well as the pointing are written in darker, almost black, ink (see pl. V).

The manuscript has no decorations except a small, very simple pen drawing that appears in the following places: on fol. 135r, indicating the haftarah for the parašah שמני (Lev 9:111:47), on fol. 171r, indicating the haftarah for the parašah ויהי (Gen 47:28-50:26); on fol. 174v (1 Kings 3:15), indicating the haftarah for the parašah מקץ (Gen 41:1-44:17); on fol. 183r (1 Kings 7:51), indicating the haftarah for the parašah פקודי (Exod 38:21-40:38); and on fol. 180v surrounding the sign of the parašah (1 Kings 7:13), although in general the parašiyyot are not marked. Another marker appears on fol. 256r (2 Kings 23:1), indicating the haftarah for the second day of Passover. On fol. 46v, the first word of a paragraph from the commentary of Ralbag on the Song of Deborah is decorated in the Islamic style.

The colophon occupies the bottom part of a column of text on fol. 262v and is written in a Sephardic semi-cursive script. It indicates that the copy was completed on Sunday, the fifth day of the month of Sivan of the year 1487, and was copied in Segovia by Abraham Alabit. The date is given by means of citing Gen 17:5 ("No longer will you be called Abram; your name will be Abraham, for I have made you a father of many nations"). The colophon states:

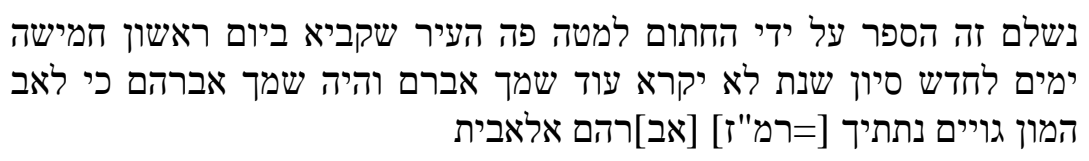

The contents of the manuscripts is as follows: Josh (fols. 140r); Judg (fols. 40r-77r); 1 Sam (fols. 77r-127v); 2 Sam (fols. 127v-168r); 1 Kings (fols. 168r-216v); 2 Kings (fols. 216v262r). There are no parašiyyot or sedarim indications. Sometimes the beginning of a haftarah is indicated in the margin, as 
in 1 Kings 3:15 or the cases already mentioned in the section on the manuscript's decoration.

The codex has some notes, such as the following on fol. 262 after the colophon:

בילא"ו ברוך נותן ליעף כח ולאין אונים עצמה ירבה

Later, also on fol. $262 \mathrm{v}$, there is a note of sale in Sephardic cursive script, quoting the name of Eliel bar Rabi Yeshua as owner of the manuscript in the year 1495 (or 1500) (2) $^{32}$ and the city of Tremecen, in North Africa:

קנין כספי אני עלאל (sic) ב"ר ישועה ס"ט בן סידון שנת מה נאוו על המיול

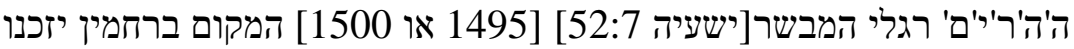

אנו ובנינו לקרות בו ולהגות עד סוף כל הדורות ... תלמסאן [פעמיים]

The part that is scratched out and almost illegible seems to repeat: .... קנין כספי אני

Below, in the center of the page, is a rather indistinct note of sale by a certain Yiṣhạaq Cohen: קניתיו אני יצחק כהן בתשעה ושלשים [...]

On fol. 39r, a note a half line long in the lower left margin in Sephardic cursive reads: התועלות המגיעים מזה הספור הם אלו

The binding of the manuscript is modern, probably from the 18th century, in leather that has faded to light brown, over cardboard, with two very slightly embossed frames, the spine with raised bands.

\section{Textual Characteristics}

The biblical text is written in Sephardic square script with very clean lines and clears pointing. The text includes some erasures and corrections made by the scribe himself-generally of plene or defective readings - which are easily spotted. Sometimes, a word that had been omitted is added by a second hand in the margin, as happens on fol. 119v, where the word רגלי is added at 1 Sam. 25:41. This is the same hand that occasionally indicates the qeré. There is a third, later hand that adds three words in Josh. 11:15 (fol. 18v), which are written vertically in the left margin of the text column and which are enclosed in a simple decoration, as if to draw the attention of the reader. The text of 2 Sam. 15:16 is missing. The scribe elongates the last letter of the line to fill in the remaining space, even letters that are not usually elongated, such as the 'ayin. Elsewhere, he compresses the letters in order to make space for an entire word, or, less frequently, he writes the letter yod to fill

\footnotetext{
32 The year could be 1495 if the first he is the millennium (5000), but if it is לפרט קטן, it is possible that the millennium is not expressed and we would have to add the two he, in which case it would be 1500 .
} 
in the space remaining in the line. There are sporadic textual corrections, as on fol. 181r, 1 Kings 7, where three lines have been scratched out and the text is written over the erasure. The text of the Targum ${ }^{33}$ is written in the right and left margins of the biblical text, in a square script of smaller size, and is vocalized (without accents).

In the manuscript, the rafeh is frequently placed on the begadkefat letters. It not only includes the two verses of Josh. 21:36-37 but also repeats them in unvocalized, consonantal form. בית־ is written as two words, for example in Josh 8:9; 9:16; 12:7 and 12:9. יששכר is pointed with a dageš in the sim, following the reading of BA, as in Josh. 19:17. בן־ ינון is pointed with a dageš in the nun, following the tradition of $\mathrm{BN}$, as in Josh 1:1; 2:1; 2:23; and 21:1. The extraordinary points in Samuel are written in the customary way (2 Sam. 19:20), with no other marks.

The manuscript rarely uses meteg, even before the hatef sewá, as can be seen in the following cases:

\begin{tabular}{|c|c|c|}
\hline Josh 19:23 & נַחְלת & 1 Sam 16:21 \\
\hline 2 Sam 21:3 & אֶעֶשה & \\
\hline
\end{tabular}

And usually the dageš is not placed in a consonant following a guttural with a šewá, as happens in:

\begin{tabular}{|c|c|c|}
\hline 2 Sam 24:5 & יעִזרר & Josh 21:3 \\
\hline Judg 18:9 & מחזְשים & 2 Kings 9:21 \\
\hline
\end{tabular}

Nor in the first letter of a word preceded by the same letter:

\begin{tabular}{|c|c|c|}
\hline 2 Kings 12:5 & על לב & Judg 9:2 \\
\hline Judg 8:10 & איש שלן & \\
\hline
\end{tabular}

When a consonant with a simple šewá is followed by the same consonant, the šewá is not replaced by a hatef patah:

\begin{tabular}{|c|c|c|}
\hline 1 Kings 8:35 & והתפלְלו & 1 Kings 8:33 \\
\hline 2 Kings 19:32 & 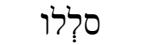 & \\
\hline
\end{tabular}

${ }^{33}$ For a detailed analysis of the readings of the Targum in this manuscript, see E. VAN STAALDUINE-SULMAN, An Electronic Edition of Targum Samuel, Kampen, 2009, p. 37-38, 59, 76, which shows that, although it is a Sephardic manuscript, its text was influenced by manuscripts copied in Italy. 


\section{Kennicott $6^{34}$}

The manuscript consists of fragments of the Former Prophets, in a single codicological unit, the work of an unknown copyist, dated in Sepharad in the 15th century. It has III+96+III fols., being its measures 265x215mm, (text block 180x155 $\mathrm{mm}$ ), without blank folios.

It is written on parchment of medium quality and medium thickness roughly polished, with some corrosion due to moisture, but in general does not hinder legibility. Fol. 96 has a tear in the upper right corner that cuts off the first word on fol. 96r and the last one on the first line of the verso. A few other folios present tears or holes due to defects in the parchment that do not affect the text (fols. 57, 66, 74, 85, 94), although others do make reading difficult (fol. 96, fol. 15 in photo, fol. 12). The two sides of the parchment are very different and the manuscript conforms to Gregory's Law.

The codex is distributed in 12 quires of 8 folios, in highly regular composition: $8^{12}$. Catchwords appear on the lower left corner of each folio in a later, Sephardic semi-cursive script, although some are absent, having been cut off during binding. The numbering of quires is written in Hebrew, probably by the scribe, in the upper right corner; it is not correlative due to the lacunas in the manuscript. Modern pagination in Arabic numerals in pencil has been added. The titles of the biblical books is written at the top of the recto of each folio, in a Latin script that is later than the one used for the book titles, indications of the biblical book and the chapter, with frequent errors. In the upper margin, the beginning of each fragment is indicated in English. The text of the Hebrew Bible is written on lines, usually 20, running the full width of the page in Sephardic square script with Tiberian pointing. Dark brown ink has been used for the biblical text and slightly lighter ink for the pointing. Drypoint ruling is barely visible on the recto side of the folios, with horizontal lines. The pricking is not visible (see pl. VI).

The manuscript lacks Masorahs; there are only some qeré readings indicated in the MP, in a lighter ink and a different hand from the text. The codex has no decorations, save some זצי ספר in the middle of the book (fol. 15v) and around the only seder marking in the manuscript, on fol. $5 \mathrm{v}$. There is also a drawing that is repeated in some margins, for no apparent reason (e. g. $80 \mathrm{v}$ or $31 \mathrm{v}$ ). It lacks colophon, date, and copyist. There are no markings for parašiyyot or sedarim except in one place: Josh. 19:50. A later hand marks the middle of each book in the mar-

\footnotetext{
${ }^{34}$ Former signatures: Codex Kenn 86. V. Dip-p-373 N.2330. Kenn 6. N. 2330. Catalogues: NEUBAUER 2330.
} 
gin, as for instance in the book of Judges (fol. 15v) or in 1 Samuel (fol. 35v). Only some of the haftarot are marked.

The contents is as follows: Josh 15:7-22:29 (fols. 1r-8v); Judg 5:26-11:20 (fols. 9r-16v) and 19:18-21:25 (fols. 17r-20r ); 1 Sam 1:1-14:4 (fols. 20v-32v) and 26:4-31:13 (fols. 33r37v); 2 Sam 1:1-24:25 (fols. 37v-65v); 1 Kings 1:1-22:8 (fols. $65 \mathrm{v}-96 \mathrm{v})$.

The manuscript present some notes, as in fol. 17r: Judicum cap. 19, pars posterior versus 18 or in fol. 39v: Mat 18 In thy name will I put my trust. I suppose my purpose will not be amiss to mention with [...] ardour, with impulsion of mind. Holy [...] put their trust in.

The binding is modern, probably from the 18th century, using cardboard and marbled paper in reddish, light-blue and yellow tones, though very faded.

\section{Textual Characteristics}

The manuscript presents a uniform text produced by a single copyist to which words that were omitted when the text was copied are added by other hands in the margins. To fill the lines, the manuscript often employs the technique of compressing the last word, but some letters are also elongated, and frequently the letter yod is written at the end of the line.

At the end of each biblical book there is a verse count. In מזרחה, שלו, Judg 21:19 (fol. 20r) there is a note above the words בת־אל, שכמה gram, partially cut off by the binding. Similar diagrams, such as the Temple drawings, appear in manuscripts of Rashi's commentaries on this passage concerning the location of Shiloh. ${ }^{35}$

In the manuscript, the rafeh is placed on the begadkefat letters and on the alef. The dageš is not placed in the nun in בן־נון, as can be seen in Josh 17:4 (fol. 2v), in Josh 19:19 and 50 (fol. $5 v$ ) or in Josh 21:1 (fol. 6r). Also, יששכר is pointed following the tradition of BA, with a dageš in the first sim (Josh 19:17, fol. 5v) and בית־אל is written as two words, as in Judg 20:31 (fol. 18v).

Meteg is rarely used, even before hatef šewá, as can be seen in the following cases:

\begin{tabular}{|c|c|c|}
\hline 2 Sam 6:1 (fol. 43r) & להַעַעחות & 2 Sam 2:21 (fol. 39v) \\
\hline Kings 21:11 (fol. 95v) & וַיעְשׁו & \\
\hline
\end{tabular}

\footnotetext{
${ }^{35}$ See M. T. Ortega-MonAsterio, «Un solo manuscrito en dos bibliotecas: el comentario de Raši a la biblia», Babelao 2 (2013), p. 135.
} 
When a consonant with a šewá is followed by the same consonant, the šewá is not replaced by a hatef patah̆, as in:

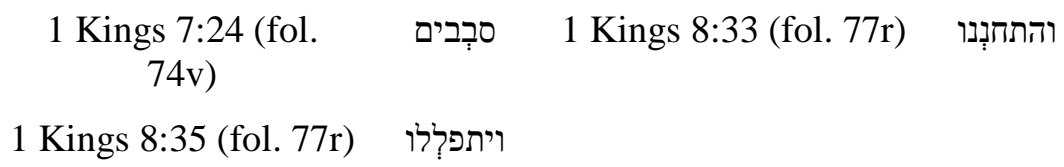

The dageš is not placed in a consonant following a guttural with a šewá:

\begin{tabular}{|c|c|c|}
\hline 1 Kings 1:7 (fol. 65v) & ויעְזרו & 1 Kings 5:3 (fol. 71r) \\
\hline 1 Kings 10:3 (fol. 80r) & ונצִלםם & \\
\hline
\end{tabular}

Nor in the first letter of a word preceded by the same letter:
1 Kings 2:4 (fol. 67v) ב בכל־לבבם 1 Kings 2:5 (fol. $67 \mathrm{v})$

1 Kings 2:32 (fol. 68v) וטבים ממנו

This Bible was used for religious readings and has some annotations in a later cursive script indicating feast days and certain weeks ( .... לשבוע שני, לחג).

\section{Kenicott $7^{36}$}

The manuscript is constituted by two codicological units. The Hebrew text corresponds to fragments of the Prophets, beginning with Isa. 39:2 up to the end of Ezekiel except for Ezek 13:2-37:19 and Minor Prophets, copied by Israel haSofer ibn R. Yișhaq ibn Israel, the Sephardi ${ }^{37}$ and dated in Toledo in 1222. It has II+248+II fols., of which 1-29 and 143178 are paper, being its dimensions $255 \times 225 \mathrm{~mm}$. (text block: 215x200 mm, including the Masorah). The blank folios are all in paper section (29v, 143r-178v). Folio 142 bis (unnumbered) is missing, but its stub remains. The last folio, number 248 , is ripped down the middle.

It is written in parchment and paper, being the former of high quality and medium thickness, with no major deterioration except some moisture stains that affect the legibility of the colophon. The manuscript conforms to Gregory's Law.

\footnotetext{
${ }^{36}$ Former signatures: Kenn. 7, N. 2331. Catalogues: NEUBAUER 2331.

${ }^{37}$ Ms. Parma 2445 ( ${ }^{\circ} 1346$ of Richler's catalogue, p. 373) mentions one Israel Ha-Sofer as the scribe of a single folio (1347-6). He is also cited in the Sassoon catalogue, p. 2, with a reference to ZunZ, Zur Geschichte und Literatur, p. 425, and in the Kiryat Sefer by Menahem ha-Meirí, Izmir edition, 1865, 8d. Israel Ha-Sofer is also the same scribe who penned ms. $44^{\mathrm{a}}$ in the Jewish Theological Seminary of New York, Lutzki 44a , dated Toledo 1241 (Hil·leli).
} 
It is distributed in 27 quires of highly irregular composition but predominantly senions, plus 65 paper folios: 29 paper fols. + $10+8+12+8^{3}+4+8+10+8+6^{4}+6^{-1}+36$ paper fols. $+6^{2}+4+6^{4}+9+$ $5+6^{2}+4$.

Quires are unnumbered. Catchwords appear only on the first 54 fols., in a later hand, in the lower left margin. Modern pagination in Arabic numerals in pencil, with an error due to the repetition of a folio before number 155 has been added. The text columns are numbered in Hebrew at the top of each one. It has no book titles. Drypoint ruling is visible on the recto side of the folios, with horizontal and vertical lines, marking the writing grid for the text and Masorah. The pricking is not visible. The hebrew text is written in Sephardic square script, in a large size for the text and a smaller size for the Masorahs with Tiberian pointing and in two columns, each generally of 17 lines. Dark brown ink has been used for the text and lighter ink for the Masorahs and vocalization.

The Masorah parva occupies the intercolumnar space, and the Masorah magna, which is very scant, occupies one line in the upper margin and another in the lower, though near the end of the manuscript it occupies two lines in the upper and three in the lower.

The manuscript lacks decorations, illuminations, and micrographies with the exception of a marking at the midpoint of the book of Jeremiah surrounded by a simple pen drawing (fol. $90 \mathrm{v}$ ) and at the midpoint of the book of Minor Prophets (see pl. IX). On fol. 129v there is a verse count for the book of Jeremiah in the form of a rhombus, and another at the end of Ezekiel (fol. 196v). No indications for parašiyyot or sedarim. No enumeration of chapters or verses. Verse counts at the end of each biblical book, including at the end of each of the Minor Prophets (see pl. VII).

On fol. 248r, difficult to decipher due to moisture damage, appears the colophon. We can gather from it that the scribe, Israel ha-Sofer ibn R. Yișhaq ibn Israel, the Sephardi, copied the complete Bible, though only the fragments bound together here remain. He writes:

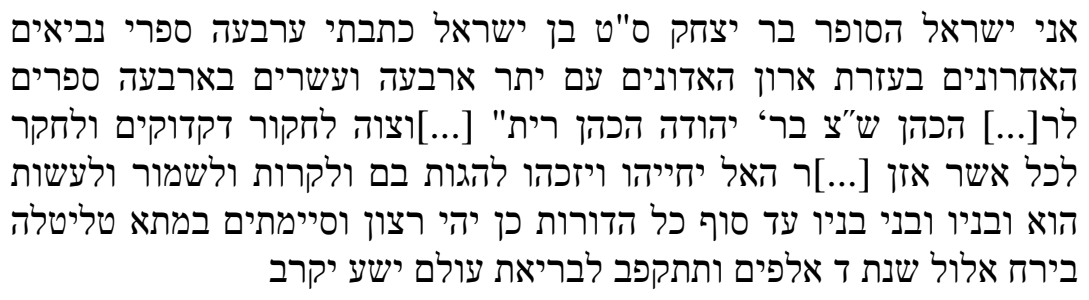

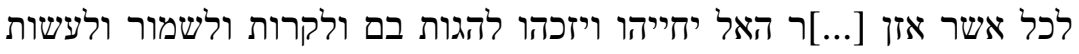

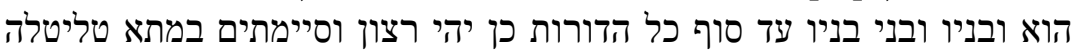

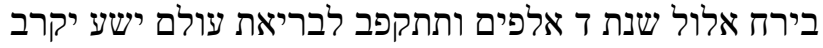

The contents of the manuscript is as follows: Reflections on the manuscript and lists of readings and variants of the same in English (fols. 1r-29v); Isa 39:2-66:24 (fols. 30r-54v); Jer 1:1- 
52:34 (fols. 54v-129v); Ezek 1:1-48:35 (fols. 129v-196v); Hosea 1:1-Mal 3:24 (fols. 197r-247v).

The manuscript has some notes. At the end of the biblical text (fol. $247 \mathrm{v}$ ) there is a text in another hand in a simpler square script, with a drawing signed by Yișhaq Hadida. ${ }^{38}$ The text is written at the beginning in judeo-spanish and later in Hebrew and is of the kind seen in the contents of amulets, and the side drawing is also of the same type used in the decoration of amulets. The text mentions blessings on who returns the book, on Mordecai, Esther, and all of Israel and maledictions against who steal the book, against Haman and the wicked. The text is difficult to read because it is blurry and because of moisture damage to the manuscript:

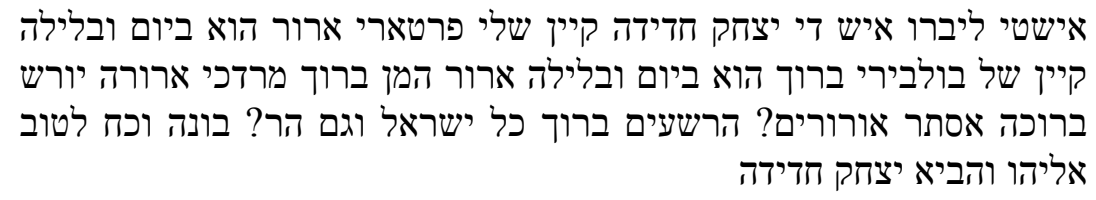

On fol. $248 v$ there is a note, probably related to a sale, in Sephardic cursive, which is illegible due to damage. According to the Neubauer catalogue, it mentions the year 1376 and the name of a witness, Moseh ha Cohen ben Yehoshua.

The manuscript is bounded in brown leather, with a small, very simple embossed frame, probably from the 17th century. The spine has raised bands.

\section{Textual Characteristics}

The English text is written in pen with brown ink and in a meticulous hand. It contains hand-written notes on the Hebrew text of the manuscript: it takes some words or passages from the Hebrew, arranges them by biblical book, and presents variants for vocalization and accentuation. The references or Masorahs in Hebrew are written in a square script and very fine handwriting. Fol. 1v says:

"This manuscript was presented to me by the Revd. Mr. Isaac Netto, on the $20^{\text {th }}$ of August 1770. Mr. Netto bought it when at Tetuan in Barbary, of a boy carrying it to a box in the Sinagogue called גניזה where all fragments of holy writings are preserved, lest they should chance to be put to improper uses. A short time after, I employed Mr. Isaac Luria carefully to compare the said MS with the best printed edition of the Hebrew Bible, which is supposed to be that printed in Amsterdam in the

\footnotetext{
38 This could be a descendant of Abraham ibn Judah Hadida, a 15thcentury Spanish Talmud scholar and author of an unpublished commentary on Ecclesiastes and Esther ("Cat. De Rossi", No. 177, Parma 2211, nº 685, 3 in the Richler catalogue).
} 
year 1667. The following are the variations he found; the observations thereon have been approved by the Revd. Mr. Netto."

From this we can deduce that the text was written by Kennicott himself. Following the text above, there is a translation of the manuscript's colophon, a list of the fragments it contains, and some general observations about the manuscript, mostly regarding pointing of the Hebrew and ways to write certain words. Beginning on fol. $3 \mathrm{v}$ and continuing up to fol. 29r is a list of variants. In some cases, there are comparisons with the readings of the Athias Bible, as the note above mentions. But Kennicott alludes to the 1667 edition: most likely he is referring to the date the edition was already begun, since it was not completed until 1679. In fact, the original collations of some of the manuscripts from the Bibliothèque Impériale de Paris with the Athias Bible are bound in the Bodleian Library under the signature Ms. Kennicott d.19.

The lists of variants are on fols. $3 \mathrm{v}-29 \mathrm{v}$. They are arranged according to biblical book and always indicate the word to which they refer according to the reading of the manuscript, the column of the manuscript where the word appears (using Arabic and Hebrew numbering), the reading offered by the printed Bible used by Luria, the vocalization or masoretic note, and a personal opinion, if there is one. Sometimes it is clearly stated that the text of the manuscript is correct, as on fol. $5 \mathrm{v}$, in reference to the word וייראו in Isa. 59:19, explaining that it is the root 'to fear' not 'to see.' Also, on fol. 12v, for the word מביאים in Jer. 33:11, it says that the manuscript is correct, pointing out that the Masorah marks this word as an exception to the rule. However, the text of $\mathrm{L}$ is defective and lacks the Masorah: מבאים, just like the text of the printed edition with which the manuscript is being compared. Moreover, a little further down on the same folio, in reference to the word הרבעית in Jer. 36:1, it says that the manuscript has the correct reading because the root of the word is רבע, and when written plene, if a yod must be omitted, it should be the first. However, in $\mathrm{L}$ it is written in the opposite way, הרביעת, with no Masorah (see pl. X).

Elsewhere, it says that the text of the manuscript is incorrect and that, by contrast, the printed edition has the correct one. For example, on fol. 3v, regarding the word נועץ in Isa. 40:14, the manuscript vocalizes the $y$ and notes that this vocalization is very strange since the qames is not found at the end of a word if it is not in pause (with atnah or sof pasuq), which is not the case here. Many of the cases that are indicated as erroneous readings in the manuscript are related to clear mistakes made by the scribe, such as switching one letter for another, as on fol. $15 \mathrm{v}$, regarding the word שובבים in Jer. 50:6, where the scribe has written a $\mathrm{D}$ instead of a ב $\mathrm{Z}$; or on fol. $16 \mathrm{v}$, where it is noted that a lis missing at the beginning of the word העמודעם in Jer. 
$52: 21$, adding that the error was taken from the previous verse, where the word does not take the conjunction. In other places, a commentator is cited, as on fol. 13v, where it says that שר סכים in Jer. 39:3 is written as two words whereas in $L$ and the rest of the manuscripts, it is written as one, adding that the Kennicott manuscript is wrong and directing the reader to Radaq's commentary on this text.

The Hebrew text of the Bible is written in a large, very clear and meticulous Sephardic square script. The filling out of lines is done through the technique of elongating some letters or repeating a letter at the end of a line, usually a yod. Sometimes, the last word is compressed. The pointing is done, as is customary, in lighter ink, as are the Masorahs. There is a very infrequent second hand in the Masorah, as on fol. 76v, which is also very meticulous, of a somewhat larger size, and which in this case completes the Masorah for the entire page. We can even find a third, much later hand, which indicates some cases of qeré, as on fol. 112v.

The manuscript rarely uses meteg. Examples can be found at:

\begin{tabular}{|c|c|c|c|}
\hline Isa $58: 2$ (fol. $44 \mathrm{v})$ & תששקלו- & MP & מתחלפ תשקְלָו- \\
\hline Jer 5:5 (fol. 60r) & אָלְכָהּה & MP & אָלְלָּהּי מתחלפ \\
\hline Jer 20:9 (fol. 79v) & בַּלכל & MP & בְַּלכל מתחלפ \\
\hline $\begin{array}{c}\text { Jer 49:28 (fol. } \\
122 r \text { ) }\end{array}$ & ולממלכות & MP & לי \\
\hline
\end{tabular}

In these cases, the reading of $\mathrm{L}$ coincides with that offered as a variant in the manuscript. Elsewhere, the variants concern accentuation, as in:

\begin{tabular}{|c|c|c|c|}
\hline Isa 60:17 (fol. 49r) & אָב $\left(2^{\text {nd }}\right)$ & MP & מתחלף אבְיא \\
\hline Ezek 39:17 (fol. 181v) & תִיתםוש & MP & תיתםוש \\
\hline
\end{tabular}

In these cases, the reading of $\mathrm{L}$ coincides with that of the manuscript.

The manuscript rarely uses meteg even before a hatef šewá, as can be seen in the following cases:

\begin{tabular}{|c|c|c|}
\hline Isa 43:14 (fol. 34v) & ברָָָניות & Isa $44: 3$ (fol. $35 r$ ) \\
\hline Jer 12:5 (fol. 69r) & תתַַחַרה & \\
\hline
\end{tabular}

A dageš is usually not placed in a consonant following a guttural with a šewá:

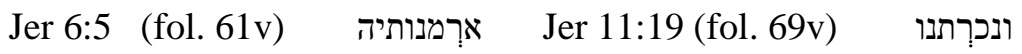

Jer 31:35 (fol. 96r) מדֶיות 
Nor in the first letter of a word preceded by the same letter:

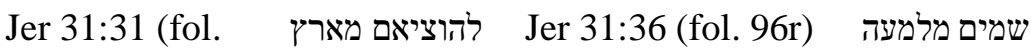
96r)

Jer 3:16 (fol. 58r) על עב

Nor is the šewá replaced by a hatef patah when a consonant with a simple šewá is followed by the same consonant, as in Jer 29:7 (fol. 91v) והתפללו.

The Masorah parva quite frequently uses the word מתחלף to indicate that there is a reading commonly found in other manuscripts but different from the one offered in the text. There are numerous cases of this throughout the text, and almost all of them concern the inclusion of meteg. The systematic treatment of this issue in the masoretic language implies that the use of meteg was a problem of special concern to the masorete. For example, in two places on fol. 180v: for האַתה (Ezek 38:17), the

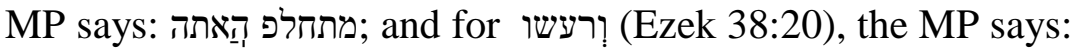
: ורעשו:

Sometimes the differences between Eastern and Western codices are cited, as on fol. 39v, in Isa 49:5. The MP for יצרי explains: למדנח כת יוצרי. Tלוגתא The expression also used to indicate that there are divergent readings, as on fol. 39v, Isa 49:5, with respect to the word לאי לו פלו The MP indicates the qeré and also says: פליג עלוי.

The MP indicates the middle verse of the Bible on fol. $61 \mathrm{v}$, Jer 6:6. Curiously, on one occasion the MP has only vowels with accents, without the consonants, on fol. 108v, Jer 39:3, beside the words סמגר־נבו.

\section{Model Codices}

The notes in the Masorah parva of the manuscript sometimes mention model codices. The Codex Babli appears only two times, one of them in combination with the Codex Muggah:

$\begin{array}{cccc}\text { Jer 7:28 (fol. 64r) } & \text { מפיהם } & \text { MP } & \text { בבבלי מפחיהם } \\ \text { Jer 29:22 (fol. 92v) } & \text { MP } & \text { MP } & \end{array}$

The Codex Muggah is quoted four times, including the one in which the Codex Babli is also mentioned:

\begin{tabular}{|c|c|c|c|}
\hline Isa 40:10 (fol. 30v) & משלָה & MP & במוגה משלָה \\
\hline Jer 4:30 (fol. 60r) & שָני & MP & במוגה שָׁני \\
\hline Jer 16:26 (fol. 76v) & ומביאי & MP & ל ובמוגה מבאי חס \\
\hline Jer 29:22 (fol. 92v) & וכאחב & MP & (sic) בבבלי וכאחיו מוגה בשטה \\
\hline
\end{tabular}


The most frequently cited model codex by far is the Codex Hilleli, appearing twelve times:

\begin{tabular}{|c|c|c|c|c|}
\hline $\begin{array}{c}\text { Jer 13:17 (fol. } \\
71 \mathrm{v})\end{array}$ & עינַי & MP & כן בהללי עינני & עינִי \\
\hline $\begin{array}{l}\text { Jer 28:12 (fol. } \\
\text { 91r) }\end{array}$ & ירמיה & MP & בהללי ירמיה דגש & L ירמיה \\
\hline $\begin{array}{c}\text { Jer 31:1 (fol. } \\
\text { 94r) }\end{array}$ & אהיְה & MP & בהללי אהיה קמ & L אהיֶה \\
\hline $\begin{array}{c}\text { Jer 31:34 (fol. } \\
\text { 96r) }\end{array}$ & למקטנם & MP & בהללי בלא דגש הקיף & למקטנם L \\
\hline $\begin{array}{c}\text { Jer 38:22 (fol. } \\
108 \mathrm{r} \text { ) }\end{array}$ & מוצאוֹת & MP & בהללי מוצווּת & L מוצאוֹת L \\
\hline $\begin{array}{c}\text { Jer 46:17 (fol. } \\
117 \mathrm{v} \text { ) }\end{array}$ & העְביר & MP & כן נקוד בהללי עִ & ה העיעביר \\
\hline $\begin{array}{c}\text { Jer 51:31 (fol. } \\
\text { 126v) }\end{array}$ & מקצה - - מקה & MP & ובהללי מקצה בלא דג & L מקצה \\
\hline $\begin{array}{c}\text { Ezek 9:6 (fol. } \\
\text { 138v) }\end{array}$ & ובתוּלה & MP & (sic) בהללי ונתוֹלה & L ובתוּלה \\
\hline $\begin{array}{l}\text { Ezek 41:5 (fol. } \\
\text { 185r) }\end{array}$ & 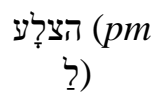 & MP & בהחחי הצלע פת & L הצלָע \\
\hline $\begin{array}{c}\text { Ezek 48:18 (fol. } \\
\text { 196r) }\end{array}$ & תבואתה & MP & בהללי תבוא דגש תַּו & תבואתה L \\
\hline $\begin{array}{l}\text { Hosea 5:2 (fol. } \\
\text { 199v) }\end{array}$ & ושַחטה & MP & (sic) בהללי ושַחטה & L ושַחטה \\
\hline $\begin{array}{c}\text { Mic 1:10 (fol. } \\
\text { 219v) }\end{array}$ & לִעַפְרָה & MP & ( לְעַפְרָה בהללי & לִעַפְרָה \\
\hline $\begin{array}{l}\text { Mic 1:14 (fol. } \\
\text { 219v) }\end{array}$ & לאֵֵכזב & MP & כן נקוד בהיל אָ & ל לאַכזב \\
\hline $\begin{array}{c}\text { Nah. 2:1 (fol. } \\
\text { 224v) }\end{array}$ & 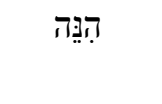 & MP & (sic) בהללי הַנהּה & 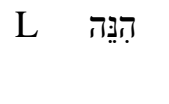 \\
\hline $\begin{array}{l}\text { Zeph. 2:14 (fol. } \\
\text { 230r) }\end{array}$ & קָאָָת & MP & בהללי קָאַת & L \\
\hline $\begin{array}{l}\text { Zech. 13:1 (fol. } \\
\text { 243r) }\end{array}$ & לחַטַטאת & MP & בהללי פת & לחַטַטאת \\
\hline
\end{tabular}

In this list, there are two places where the reading of the MP is marked sic due to the fact that it does not differ at all from the text (Hosea 5:2 and Mic 1:10). Perhaps the masorete merely wished to emphasize that this was the correct reading. The other two passages with sic (Ezek 9:6 and Nah 2:1) are thus marked because the reading proposed for the Codex Hilleli is not possible. In Jer. 13:17 the pointing in the manuscript differs 
from that of L, but its reading is documented by the model codex.

The similarities between this manuscript and ms. $44^{\mathrm{a}}$ at the JTS in New York are many, not only in the arrangement and graphic aspects, but also in the importance given to the readings of the Codex Hilleli, as we saw above.

\section{Final Remarks}

Following the study of the Sephardic Bibles in the Kennicott collection (with the exception of Ms. Kennicott 1, as was noted above), we can state that, although it is not a unified collection, taken together the Kennicott Bibles provide an excellent sampling of biblical manuscripts of high textual quality. It is clear that Kennicott collected a greater number of Sephardic Bibles, probably because of the good reputation that the texts of these Bibles enjoyed. His primary objective was a critical edition of the Hebrew text of the Bible and this is demonstrated by the numerous collations among different manuscripts he made during his trips to European libraries. The textual research on the Bibles reveals that the majority of the codices preserves the pristine textual tradition of Ben Asher and confirms once again the accuracy of the Sephardic texts. The manuscripts in this collection contain notes and other evidence of direct work with these texts, especially in the case of Kennicott 7. The Bodleian Library has preserved an exceptional collection tied to the work of one of the early librarians and Hebraists, thanks to which we are also able to observe the working methods and the research interests of the biblical scholars of his time.

\section{Bibliography}

$M^{a}$ Josefa DE AzCÁRRAGA, «The Ortographic Irregularities in the Manuscript M1 of the Library of the Universidad Complutense de Madrid», Sefarad 59 (1999), p. 239-250.

Francisco J. DEL BARCo DEL BARCo, Catálogo de Manuscritos Hebreos de la Comunidad de Madrid, I, CSIC, Madrid, 2003.

Malachi BeIT ARIÉ, Catalogue of the Hebrew Manuscripts in the Bodleian Library. Supplement of Addenda and Corrigenda to Vol. I (A. Neubauer's Catalogue), Oxford, 1994.

ID., Unveiled Faces of Medieval Hebrew Books, Jerusalem, 2003.

ID., The Makings of the Medieval Hebrew Book : Studies in Paleography and Codicology, Jerusalem, 1993.

Menahem CoHen (ed.), Miqraot Gedolot Haketer, vol. 11, Jerusalem, 1995. 
Christian D. GinsBURG, Introduction to the MassoreticoCritical Edition of the Hebrew Bible. With a Prolegomenon by H. M. OrLiNSKY, New York, 1966.

Rimon KasHER, תוספות תרגום לנבאים (Targumic Toseftot to the Prophets), Jerusalem 1996.

Katrin Kogman-ApPeL, Jewish Book Art between Islam and Christianity. The Decoration of Hebrew Bibles in Medieval Spain, Leiden - Boston, 2004.

Benjamin KenNicotT, A dissertation in two parts: Part the first compares I Chron. XI with 2 Sam. V and XXIII; and part the second contains observations on seventy hebrew mss, with an extract of mistakes and various readings, 2 vols., Oxford, 1753.

ID., The ten annual accounts of the collation of hebrew mss of the old testament : Begun in 1760 and compleated in 1769. Oxford - Cambridge - London, 1770.

ID., The state of the collation of the hebrew manuscripts of the Old Testament : At the end of the ninth year, Oxford - Cambridge - London, 1768.

Bezalel NARKISS, Hebrew Illuminated Manuscripts in the British Isles, 2 vols., Jerusalem - London, 1982.

Bezalel NARKiss and Aliza CoHEn-Mushlin, The Kennicott Bible. Facsimile Editions, London 1985.

Adolph Neubauer, Catalogue of the Hebrew manuscripts in the Bodleian Library, 2 vols., London, 1896-1906.

Karl O. NoRDSTRÖM , «The Temple Miniatures in the Peter Comestor Manuscript at Madrid (Bibl. Nac. Cod. Res. 199)», in Joseph GuTmann, No Graven Images. Studies in Art and the Hebrew Bible, New York, 1971, 39-74.

$\mathrm{M}^{\mathrm{a}}$ Teresa Ortega-Monasterio, «El texto de los Códices Modelo según el 'Or Torah de Menahem de Lonzano», in N. FERNÁNDEZ MARCOS, J. TREBOLle BARRERA Y J. FERnÁndez VAllina (eds.), Simposio Bíblico Español, Madrid, 1984, 193-212.

ID., «Los códices modelo y los manuscritos hebreos bíblicos españoles», Sefarad 65 (2005), p. 353-383.

ID., «Un solo manuscrito en dos bibliotecas: el comentario de Raši a la biblia», Babelao 2 (2013), p. 123-139.

Binyamin Richler, Hebrew manuscripts in the Biblioteca Palatina in Parma : catalogue, Jerusalem, 2001.

Eveline van StaAlduine-Sulman, The Text of Samuel, Leiden, 2002.

ID., An Electronic Edition of Targum Samuel, Kampen, 2009. 
Gabrielle SED-RAJNA, «Toledo or Burgos», Journal of Jewish Art, 2 (1978), p. 6-21.

Barry WaLFISCH, The Frank Talmage Memorial Volume, I, Haifa, 1993.

Gérard WeIL, Massorah Gedolah. Manuscrit B19a de Léningrad, Rome, 1971.

http://sfardata.nli.org.il

Abbreviations

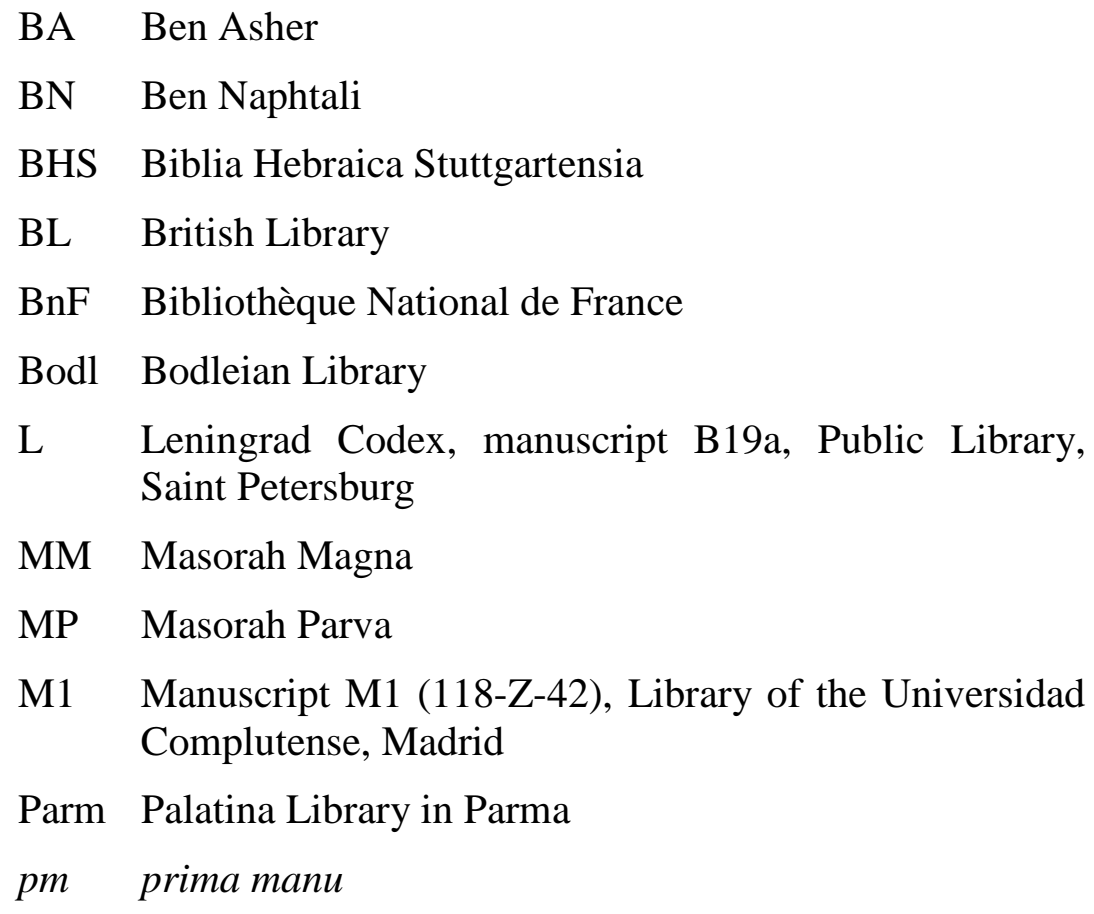

\section{Abstract}

Benjamin Kennicott (1718-1783), important Hebraist and librarian at the Radcliffe Library, gathered a number of Hebrew Bible manuscripts, kept nowadays in the Bodleian library. It is a collection of nine bibles, being seven of them of Sephardic origin; only two were copied in Ashkenaz and one in Italy. Until the present days, the only complete catalogue of those manuscripts is Neubauer's, dated in 1886, which obviously does not include codicological aspects. The present work is focused in a detailed study of the bibles in this collection copied in the Iberian Peninsula, excluding the famous Kennicott Bible (Ms. Kenn 1), which has been already described and studied. The work on each manuscript is two folded: the first part corresponds to the description and in the second part textual aspects of the manuscript are presented.

\section{Key words}

Hebrew Bible, Hebrew text, Sephardic manuscripts 


\section{PLATES}

Pl. 1.- Bodleian Library, Ms. Kennicott 9, f. 1v

Pl. 2.- Bodleian Library, Ms. Kennicott 2, f. 76r

Pl. 3.- Bodleian Library, Ms. Kennicott 2, f. 76r, parašah sign

Pl. 4.- Bodleian Library, Ms. Kennicott 4, f. 86r

Pl. 5.- Bodleian Library, Ms. Kennicott 5, f. 22v

Pl. 6.- Bodleian Library, Ms. Kennicott 6, f. 5v

Pl. 7.- Bodleian Library, Ms. Kennicott 7, f. 90v

(With permission of the Keeper of Special Collections of the Bodleian Library, Letter $4^{\text {th }}$ February 2016) 
Sibes discrepandiarini?

qua reperiunuer in Tharque, scel Parry ind si Chaldain iniam Bibleorum' magnorie, ma simeque deqanlui, ac pretiosorum, qua in 'Ya licana Bibliothera' adservantur; quorum 1. mun cupatur Biblia Regia, cacusa in membrana. An

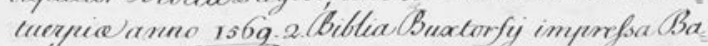
silere anno, big. s. Biblia manuscripta in merntro. no anmo a Grealione Mundi soss. ab. Ldvenlu. Christi nostrings. Frbino in Tatic. Bibliother'inlata

C) magne quedeme curve, alque sereden desoriplassune ommes

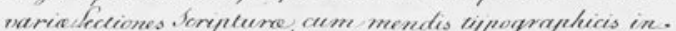
irilus columnis, inter queas elapita, 8 Commaca Bibli.

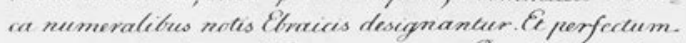

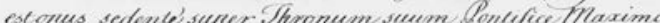

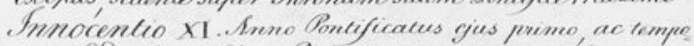

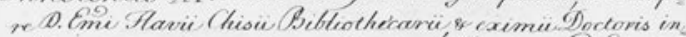

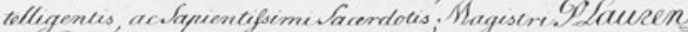

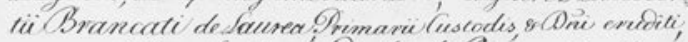

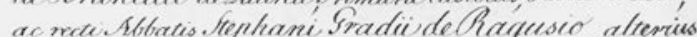

Cuscodis. Sdque feria proma, Ralendes menses Sebureamic, anno $16 \%$ yer mé minimum Shleum Morosirume

dim Sarnuetem filium Davidis e SamiliabBen Sachemiars, Yencuem. Quemadrriodume aue. ceme dignus fue, quic tiocre opus perfe. cerrm; ila quoque dignum me redac Yesus. Mamutruus, ue a. lies libmo coombat, ad San clificrrionesm. Pominis Siri Palvis, Filii, ef pivilus efandi,

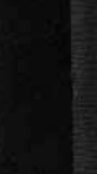

(Pl. 1) 


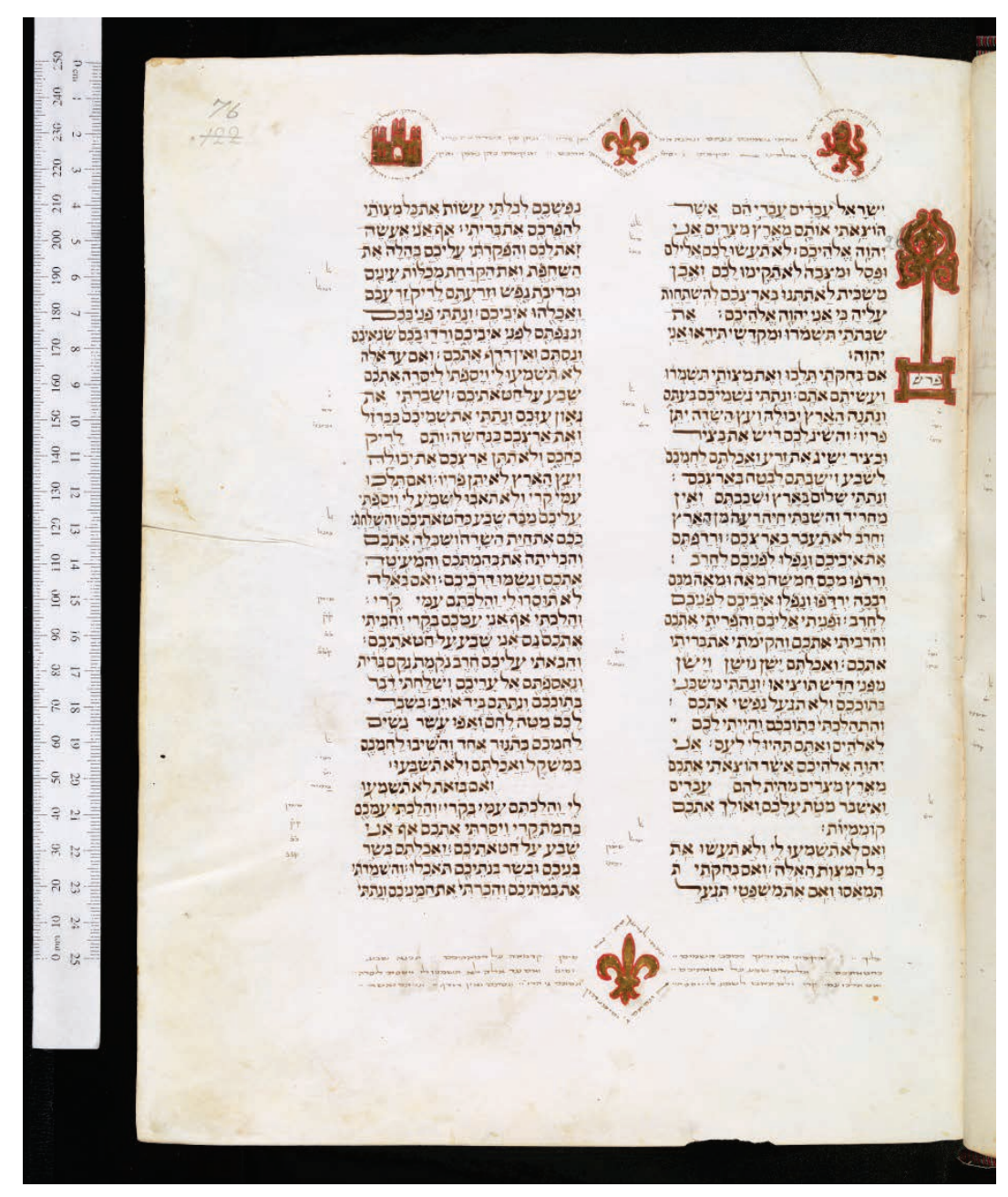

(Pl. 2) 


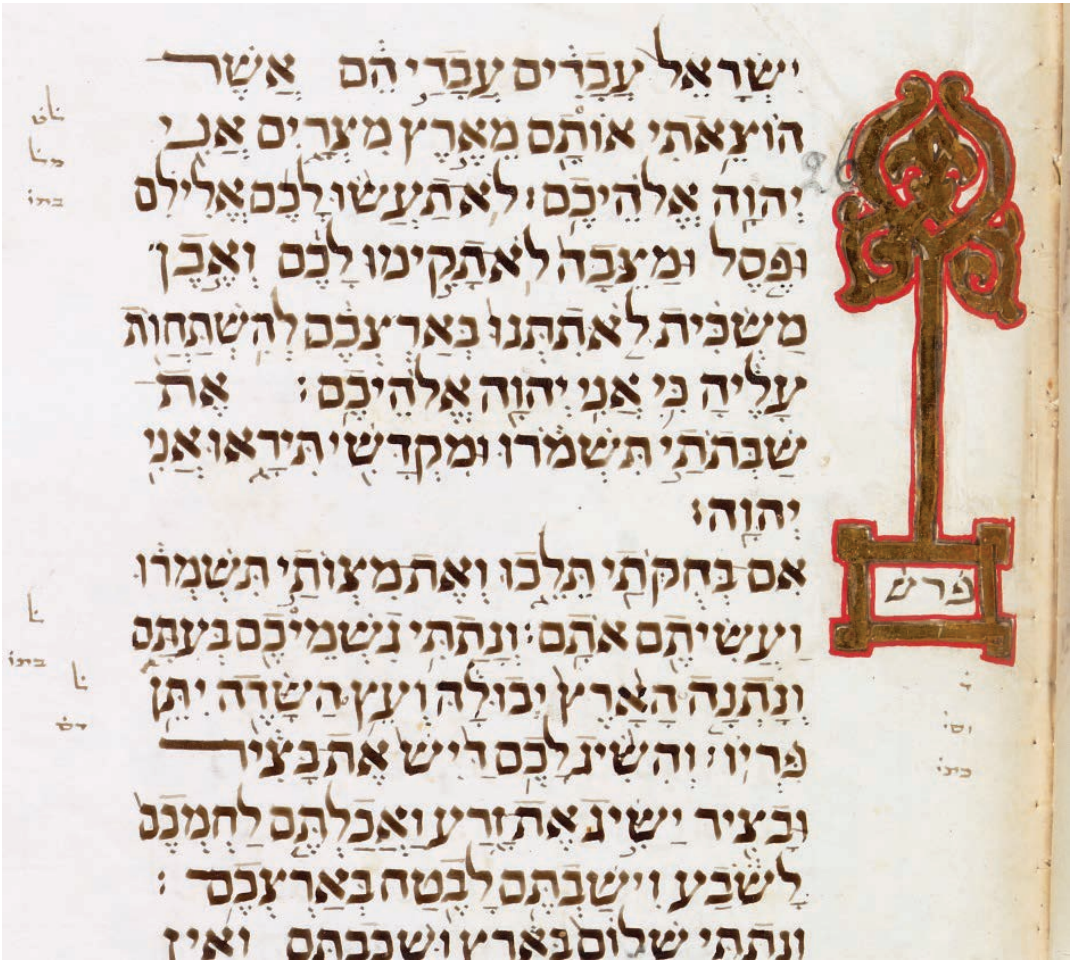

(Pl. 3) 


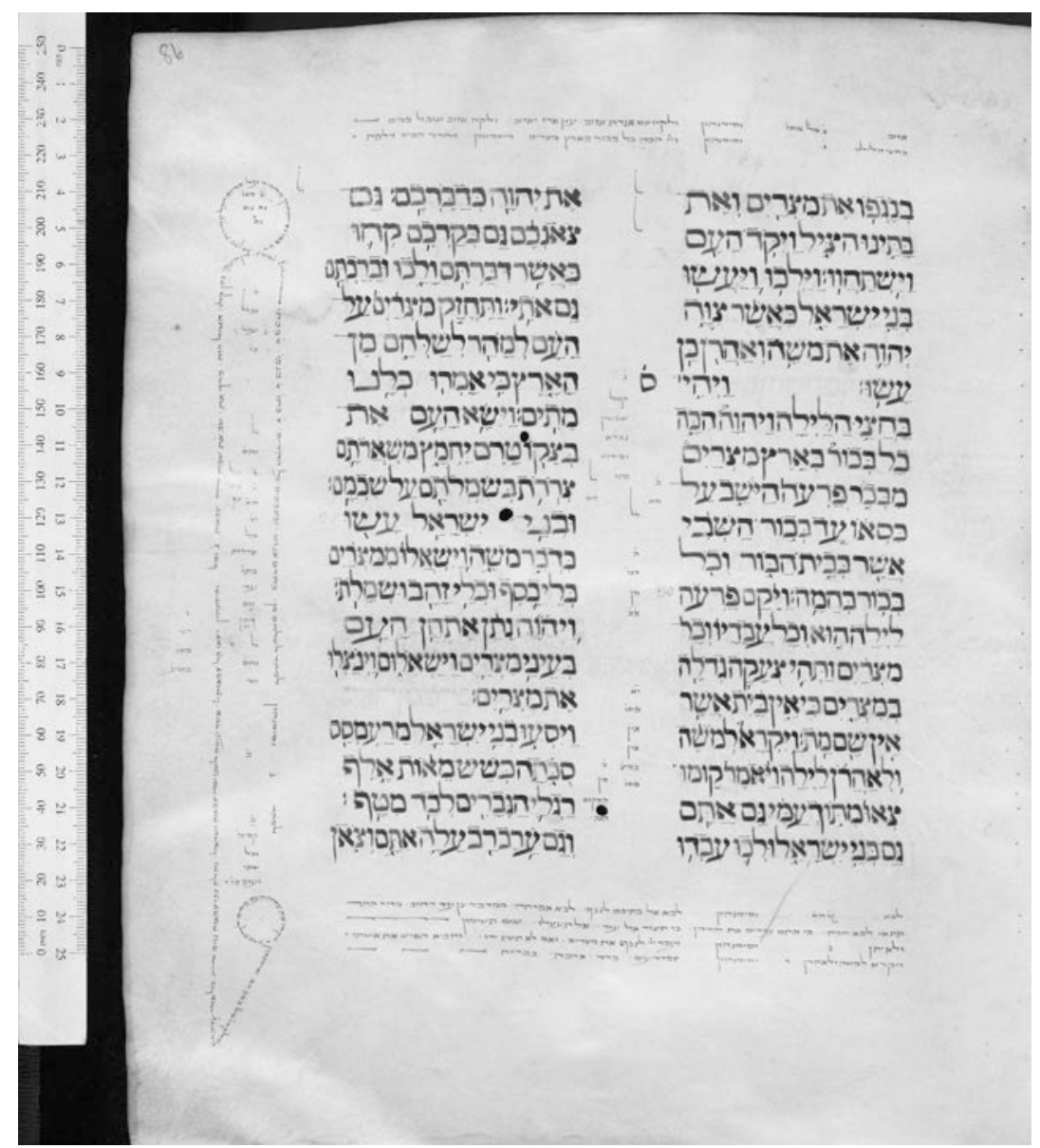

(Pl. 4) 


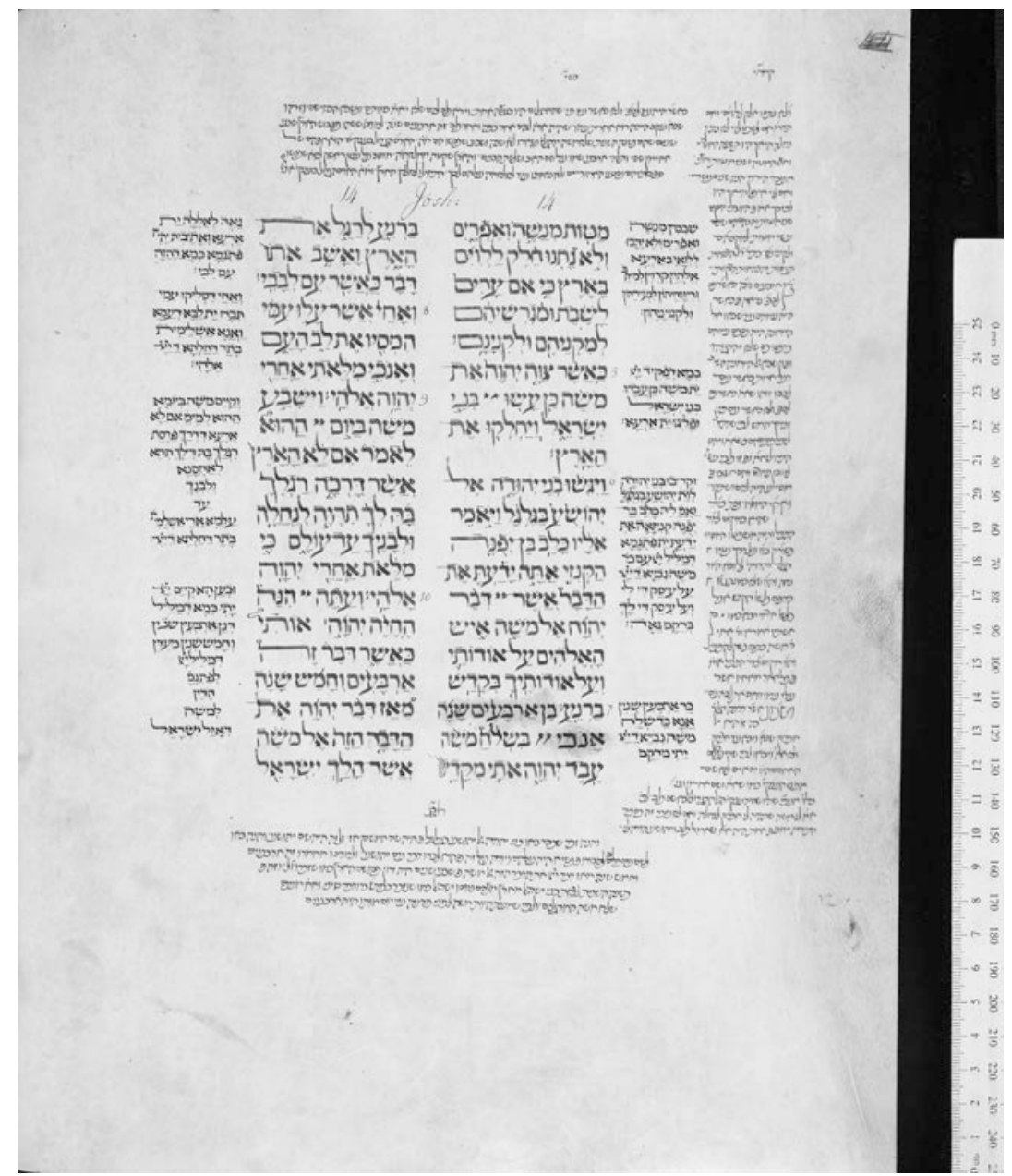

(Pl. 5) 


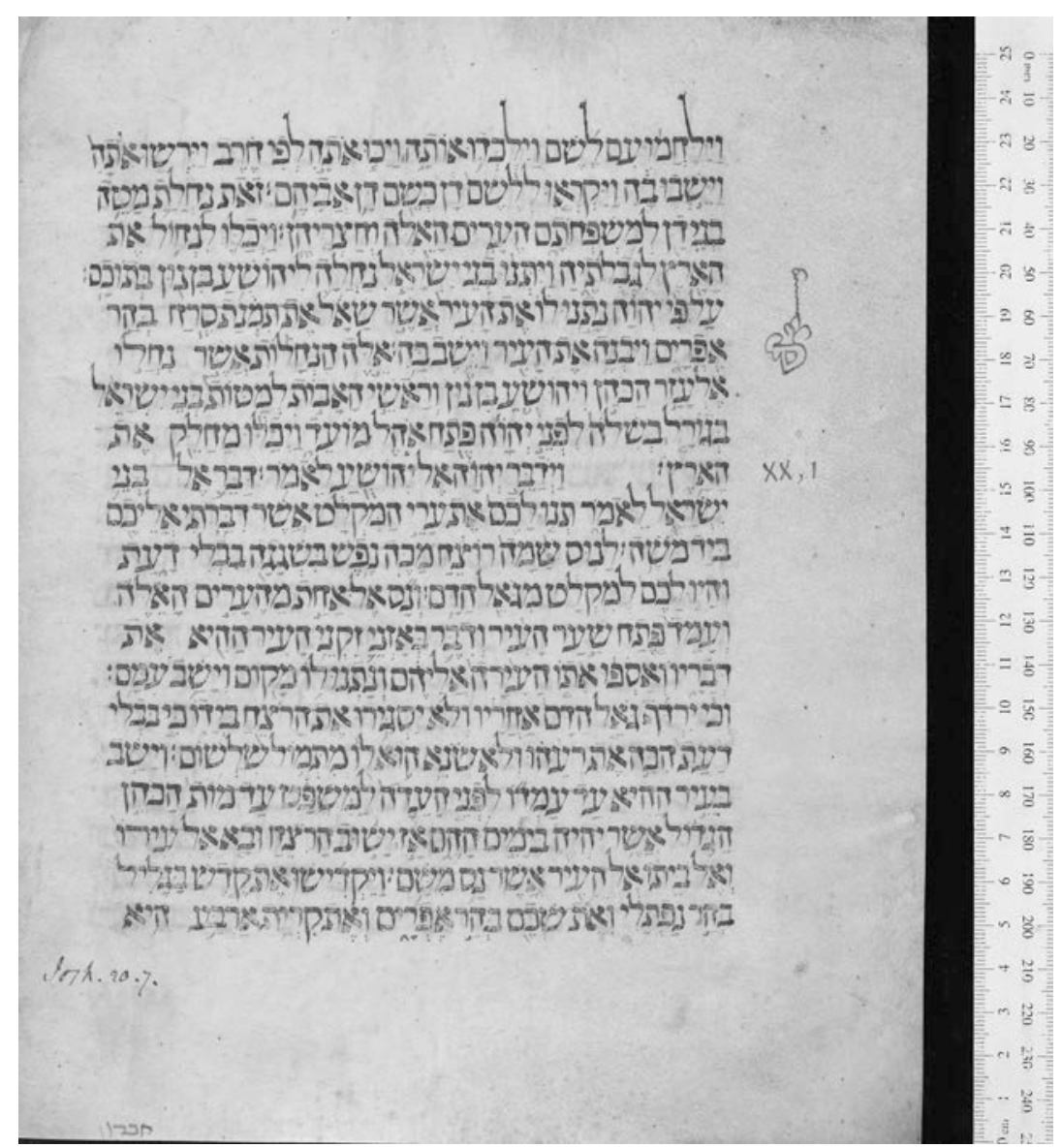

(Pl. 6) 


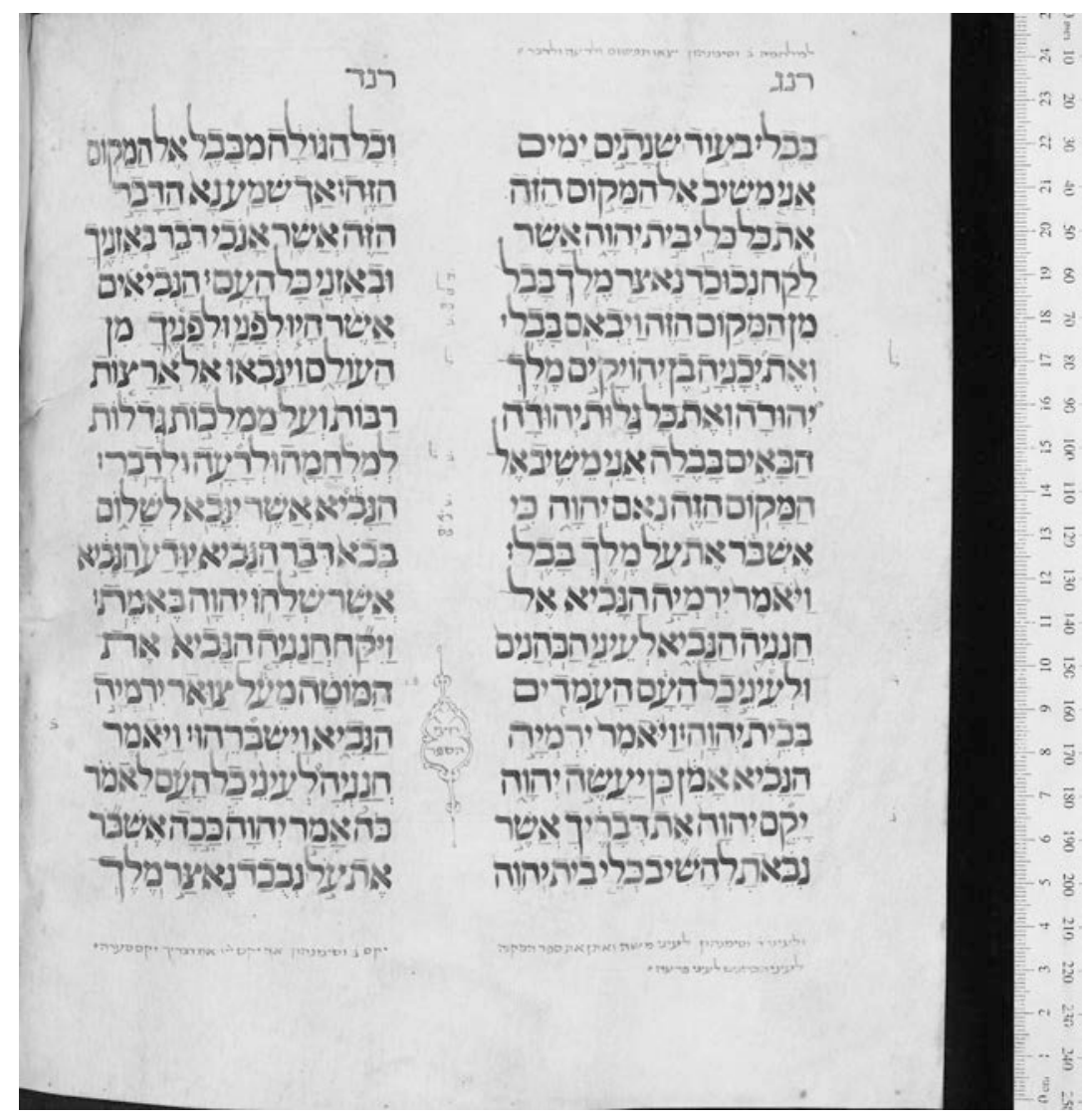

(Pl. 7) 